\title{
Challenge to the Pro-democracy Movement in Hong Kong
}

Political Reforms, Internal Splits and the Legitimacy Deficit of the Government

Joseph Y. S. Cheng

\section{CpenEdition}

\section{Journals}

Electronic version

URL: http://journals.openedition.org/chinaperspectives/5563

DOI: $10.4000 /$ chinaperspectives.5563

ISSN: 1996-4617

\section{Publisher}

Centre d'étude français sur la Chine contemporaine

\section{Printed version}

Date of publication: 30 July 2011

Number of pages: $44-60$

ISSN: 2070-3449

Electronic reference

Joseph Y. S. Cheng, "Challenge to the Pro-democracy Movement in Hong Kong », China Perspectives [Online], 2011/2 | 2011, Online since 30 June 2014, connection on 28 October 2019. URL : http:// journals.openedition.org/chinaperspectives/5563; DOI : 10.4000/chinaperspectives.5563

(C) All rights reserved 


\title{
Challenge to the Pro-democracy
} Movement in Hong Kong

\author{
Political Reforms, Internal Splits and the Legitimacy Deficit of the Government
}

\author{
IOSEPH Y. S. CHENG*
}

ABSTRACT: This article intends to examine the challenges facing the pro-democracy movement in Hong Kong today, as well as the general political and social situation in the territory. It argues that the deterioration and divisions within the pro-democracy movement may not be political gains for the pro-Beijing united front, as the political and social polarization poses serious problems for effective governance as well. An administration threatened by legitimacy deficit will find it increasingly difficult to deliver in terms of both economic development and social services, thus forcing itself into a vicious circle as unsatisfactory performance further worsens its legitimacy deficit.

Though Hong Kong people's confidence in China and their trust for the Chinese leadership as well as their identification with the Mainland have been strengthening since the territory's return to China, the latter's strong backing for the HKSAR has become a double-edged sword. Hong Kong people realize that decisions on local political reforms are made in Beijing, and they also partly blame the Chinese authorities for the unsatisfactory performance of the HKSAR government which is picked by and accountable to Beijing. The lose-lose situation can only be reversed by the enlightenment of the Chinese leadership which, hopefully, would feel secure enough to allow genuine democracy in the territory.

KEYWORDS: Pro-democracy movement, electoral reforms, internal splits, legitimacy deficit, pro-Beijing united front, social polarization, and "post-80s generation"

$\mathrm{T}$ he Hong Kong Special Administrative Region (HKSAR) government released the document "Methods for Selecting the Chief Executive and for Forming the Legislative Council in 2012" (henceforward referred to as the "Political Reform Proposals") in November 2009. It did not, as demanded by the territory's pro-democracy movement, provide a concrete timetable and roadmap for the election by universal suffrage of the Chief Executive in 2017 and of all seats in the Legislative Council in 2020. This was very disappointing from the movement's perspective.

The contents of the Political Reform Proposals were nevertheless not at all surprising. Rather, the divisions within the pro-democracy movement overall suggest that a permanent split within the movement has become inevitable. (1) Further, in the eyes of Hong Kong people, the Chinese leadership and the HKSAR government are not interested in the promotion of genuine democracy, and its implementation has now become uncertain.

A political movement that has been in opposition since its birth in the 1980s and that has no prospect of securing political power has inevitably become divided in strategy and tactics, with one segment acting in moderation and pursuing negotiations with the authorities, and another segment opting for radicalism. This split reflects increasing polarisation in Hong Kong society as well, as the majority becomes more and more apathetic and a significant minority demonstrates rising frustration and anger, not only over the stagnation in the democratisation process, but also over the widening gap between rich and poor.

This article intends to examine the challenges facing the pro-democracy movement in Hong Kong today, as well as the general political and social situation in the territory. It argues that the deterioration and divisions within the pro-democracy movement may not be political gains for the
pro-Beijing united front, as political and social polarisation poses serious problems for effective governance as well. An administration threatened by legitimacy deficit will encounter increasing difficulty in its provision of economic development and social services, thus forcing itself into a vicious circle as unsatisfactory performance further worsens its legitimacy deficit.

\section{The progress or lack of progress in electoral reforms}

The attempt to introduce Article 23 legislation (2) and the difficult economic situation caused by the Severe and Acute Respiratory Syndrome

Joseph Y.S. Cheng is Chair Professor of Political Science at the City University of Hong Kong (Email: rcccrc@cityu.edu.hk), editor of The Journal of Comparative Asian Development and the Hong Kong Journal of Social Sciences (香港社會科學學報, xianggang shehui kexue xuebao). One of his last books is: Joseph Y. S. Cheng (ed.), Whither China's Democracy? Democratization in China since the Tiananmen Incident, Hong Kong, City University of Hong Kong Press, 2011.

1. See, for example, the column by Lee Sin-Chi entitled "Jianzhipai dali zaoshi, fanmin fenlie cheng dingju,"(The establishment strenuously building a favourable environment, the pan-democratic camp destined to split), Ming Pao, 21 December 2009, p. A4.

2. Article 23 of the Basic Law (Hong Kong's constitution) states: "The Hong Kong Special Administrative Region shall enact laws on its own to prohibit any act of treason, secession, sedition, subversion against the Central People's Covernment, or theft of state secretes, to prohibit foreign political organizations or bodies from conducting political activities in the Region, and to prohibit political organizations or bodies of the Region form establishing ties with foreign political organizations or bodies." This article was written into the draft Basic Law after the massive protest rallies in Hong Kong during the Tiananmen Incident in 1989; obviously, the Chinese authorities were concerned about a repetition of such activities. The Tung administration was wise enough not to initiate the controversial legislative process during his first term. In response to the open promotion of the Chinese authorities, a paper addressing the implementation of Article 23 of the Basic Law was finally unveiled for public consultation in September 2002. As expected, the proposals stirred fears of a crackdown on human rights groups and Falun Gong. The territory's pro-democracy camp also perceived the proposals as a threat to civil liberties. See South China Morning Post, 25 September 2002. 
(SARS) epidemic prompted more than half a million people to take to the streets in protests demanding democracy. ${ }^{(3)}$ In response, the HKSAR government established the Constitutional Development Task Force in January 2004. It also decided to initiate the mechanism for amending the electoral methods for the Chief Executive and the Legislative Council in accordance with the National People's Congress Standing Committee (NPCSC) interpretation of April 2004, in an attempt to strengthen the democratic elements of the Chief Executive election in 2007 and the Legislative Council elections in 2008.

The HKSAR government in October 2005 announced a package of proposals to reform the electoral systems starting in 2007/2008. The package suggested including all District Council members in the Election Committee for the election of the Chief Executive, ${ }^{(4)}$ and expanding the Legislative Council from 60 to 70 members, with one additional seat for each of the five geographical constituencies, and another five to be elected from among the District Council members. Later in November 2005, the Chief Executive also initiated discussions on the models, roadmap, and timetable for implementing universal suffrage through the appointed Commission on Strategic Development.

In the following month, pro-democracy legislators vetoed the electoral reform package. They could not accept that both the central government and the HKSAR government had refused to provide a concrete roadmap and timetable for the implementation of universal suffrage for the election of the Chief Executive and the entire legislature. They were also against the retention of appointed and ex-officio members in the District Councils.

The defeat of the HKSAR government's electoral reform package meant that the existing electoral methods would continue to apply. The prodemocracy movement believed that Beijing and the HKSAR government had no sincere intention to implement genuine democracy in Hong Kong, while the pro-Beijing united front attacked the pro-democracy groups for blocking progress in electoral reforms and delaying the democratisation on process. Meanwhile, from the end of 2005 to mid-2007, the Commission on Strategic Development continued its task.

The HKSAR government released the Green Paper on Constitutional Development on 11 July 2007 to consult the public on the options, roadmap, and timetable for implementing universal suffrage for the elections of the Chief Executive and the Legislative Council. On 12 December 2007, Donald Tsang submitted a report to the NPCSC. Meanwhile, opinion surveys in Hong Kong in the past decade or so have consistently showed that around 60 percent of the population support the prompt implementation of universal suffrage for the elections of the Chief Executive and the entire legislature (referred to as "dual universal suffrage"). The pro-democracy groups that have been demanding immediate implementation of "dual universal suffrage" also succeed in securing about 60 percent of the votes in the direct elections to the Legislative Council (they won even more votes in earlier elections). Hence, the Donald Tsang administration in its report to the NPCSC acknowledged that more than half of the public supported the implementation of "dual universal suffrage" in 2012, although it also pointed out that introducing universal suffrage to the Chief Executive election no later than 2017 would stand a better chance of acceptance by the majority of the Hong Kong community.

The NPCSC soon announced its "Decision on Issues Relating to the Methods for Selecting the Chief Executive of the HKSAR and for Forming the Legislative Council of the HKSAR in the Year 2012 and on Issues Relating to Universal Suffrage" on 29 December 2007. The decision stipulated:
"The election of the fifth Chief Executive of the HKSAR in the year 2017 may be implemented by the method of universal suffrage; that after the Chief Executive is selected by universal suffrage, the election of the Legislative Council of the HKSAR may be implemented by the method of electing all the members by universal suffrage."

The Donald Tsang administration and the pro-Beijing united front have since been arguing that the timetable for implementation of "dual universal suffrage" has been set. But the pro-democracy movement is certainly right in criticising this as far from a concrete timetable and firm commitment; they argue that the decision of the NPCSC may be interpreted as follows: "If the conditions are ripe, then the 'dual universal suffrage' may be implemented by 2017 and 2020 (the date of the Legislative Council elections following the Chief Executive election in 2017); and if the conditions are not yet mature, caution is advised and delay may be prudent."

Further, the nomination procedure of the Chief Executive election remains controversial. According to Article 45 of the Basic Law, the "ultimate aim is the election of the Chief Executive by universal suffrage upon nomination by a broadly representative nominating committee in accordance with democratic procedures." It is generally expected that the existing Election Committee electing the Chief Executive will then serve as the nominating committee; and according to Article 4 of Annex I to the Basic Law: "Candidates for the office of the Chief Executive may be nominated jointly by not less than 100 members of the Election Committee. Each member may nominate only one candidate." The Election Committee is expected to have 1,200 members in 2012, with 300 members elected from each of the following four sectors: industrial, commercial, and financial sectors; the professions; labour, social services, religious, and other sectors; members of the Legislative Council, representatives of district-based organisations, Hong Kong deputies to the NPC, and representatives of Hong Kong members of the National Committee of the Chinese People's Political Consultative Conference (CPPCC).

Since the elections to the Election Committee are heavily biased in favour of the establishment, the pro-democracy movement may not be able to win enough seats in the nominating committee to nominate its candidate; i.e., if the threshold for nomination is set too high, there will not be genuine competition, and the people of Hong Kong can only elect someone from a shortlist of candidates approved by the Chinese leadership.

Hong Kong people well remember that in the election of the Chief Executive in 2002, a change of procedures made the Election Committee's nomination of candidates an open process. As a result, more than 700 members nominated $\mathrm{C}$. $\mathrm{H}$. Tung, and there were not enough votes left to nominate another candidate; Tung was elected for second term on an ipso facto basis. Then, in the election of the third term Chief Executive in June 2005, the pro-democracy movement candidate, Democratic Party chairman Lee Wing-tat, could not even secure the 100 votes necessary to qualify as an official candidate. In the fourth term Chief Executive election in 2007, the pro-democracy movement candidate, Alan Leong Kah-kit, managed to qualify as an official candidate and engage in debates with Donald Tsang, who was seeking re-election. But the pro-democracy movement

3. See Joseph Y. S. Cheng (ed.), The July 1 Protest Rally - Interpreting a Historic Event, Hong Kong, City University of Hong Kong Press, 2005.

4. At that time, Hong Kong was divided into 18 districts, with District Councils serving as local advisory bodies. There were about 400 members elected by small single-member constituencies, and more than 100 appointed members and ex-officio members who were chairmen of Rural Committees. 
only secured between 130 and 140 seats in the Election Committee, and it would have been extremely difficult for it to do better.

Proposals from pro-Beijing united front figures, including members of the Committee for the Basic Law of the HKSAR under the NPCSC, have alarmed the pro-democracy movement. These suggestions use the pretexts of orderly competition and ensuring the broad representativeness of the candidates to block the presentation of a candidate from the prodemocracy movement. Most of these proposals aimed to raise the nomination threshold; for example, nomination should require the endorsement of 200 (25 percent) instead of 100 members of the nomination committee, nomination should require the endorsement of a specific number of representatives from each the four sectors, and nomination should require the support of a number of Hong Kong deputies to the NPC. In response to these proposals, the pro-democracy movement has demanded that the nomination threshold for candidates in the Chief Executive election should be no higher than the existing one.

Regarding the elections in 2012, the NPCSC decision in December 2007 stipulates that universal suffrage would as before apply to only half of the seats of the legislature. Further, half of the seats would still be returned by functional constituencies, and the procedures for voting on bills and motions in the Legislative Council would also remain unchanged. The latter actually means that the majority of functional constituency seats would retain veto power over initiatives by pro-democracy legislators.

In the eyes of the Hong Kong community, if the scope of electoral reforms is so limited for the elections in 2012, how can one expect significant progress in the years after 2012 and before 2017 and 2022? There are suspicions that the Chinese authorities have been adopting delay tactics, postponing the crucial issues of electoral reform until 2015 or 2016. Various statements made by key establishment figures soon after the release of the Political Reform Proposals have raised strong doubts as to whether the Chinese authorities are really determined to abolish functional constituencies by 2020. On 20 November 2009, Maria Tam, a Hong Kong deputy to the NPC and a member of the Committee for the Basic Law of the HKSAR under the NPCSC, indicated to the media that if the Legislative Council seats returned by functional constituencies conform to the principle of equality, they would qualify as election by universal suffrage; she further stated that universal suffrage would be defined by the central government in Beijing according to the Basic Law, and not in line with the International Covenant on Civil and Political Rights. ${ }^{\left({ }^{5}\right)}$ A day earlier, Chief Secretary Henry Tang Ying-yen (a leading contender for the Chief Executive post in 2012) declared that a system of "one man, two votes" would still be "fair and equal" if everyone had a chance to vote in the functional constituencies. ${ }^{(6)}$ Hence, the abolition of functional constituencies has become the most important theme in the present campaign for genuine democracy.

In the electoral reform process in recent years, the autonomy of the HKSAR government appears to have been eroding. During Donald Tsang's campaign for re-election as Chief Executive in early 2007, he told journalists that he would "engage in a tough game" to settle the challenging issue of political reform. In his first policy address after re-election, he stressed that he had a constitutional duty to resolve the question of political reform in the territory. After the release of the Political Reform Proposals in late 2009, however, both central government officials and the Tsang administration indicated that Hong Kong did not have the authority to tackle political development beyond 2012 in the political reform package. So, when did the Donald Tsang administration lose the authority to handle political reform beyond 2012? When did the central government take back this authority from the HKSAR government? Both the central government and the HKSAR government still owe Hong Kong people an explanation.

When Hong Kong people study the Basic Law, their understanding has always been that amendments to the method for selecting the Chief Executive after 2007 require the endorsement of a two-thirds majority of the full legislative Council, the consent of the Chief Executive, and the approval of the NPCSC.

Similarly, amendments to the method for forming the Legislative council can be made only with the endorsement of a two-thirds majority of the full Legislative Council and the consent of the Chief Executive; and it has to be reported to the NPCSC for record.

There are no stipulations in the Basic Law that the HKSAR government must seek the authorisation of the NPCSC before it can tackle the roadmap and timetable for political reforms beyond the present term.

During the drafting of the Basic Law, Hong Kong people were not aware that there had been such discussions on the prerequisite of NPCSC authorisation. Nonetheless, it is apparent that the HKSAR government must seek the NPSCS's authorisation before it seeks to abolish functional constituencies in the Legislative Council by 2020.

Maria Tam's statement on universal suffrage in Hong Kong also raises serious questions. Was the HKSAR government consulted on this? If so, why didn't the Donald Tsang administration consult the Hong Kong community, or at least inform it of the "new policy"? It is certainly inappropriate to have such a significant decision revealed to the Hong Kong people during a television talk-show.

There were rumours within local media circles in mid-2010 that some pro-Beijing legal experts in Hong Kong were working to produce a definition of "universal and equal representation" applicable to the territory's future political reform packages. There was no indication whether the Donald Tsang administration was involved in this work.

After meeting the democratic Party delegation on the political reform issue, Li Gang, deputy Director of the Central Liaison Office in Hong Kong, was at pains to explain to the media that his office was not a "second governing team" in the territory. ${ }^{(7)}$ This was actually the first local press conference by the leadership of the Central Liaison Office; why should Li Gang consider the issue of the "second governing team" something to be clarified in this first press conference, when no reporter raised the issue? Certainly he realised that many Hong Kong people had this perception; and it was more than the "personal comment" made by his former colleague Cao Erbao in an article published in the Study Times of the Central Party School in Beijing. ${ }^{(8)}$

When the central government authorised the Central Liaison Office to meet with the pro-democracy group in Hong Kong, it should have carefully considered whether these groups should assume the role of receiving messages from the entire Hong Kong community and serving as a bridge be-

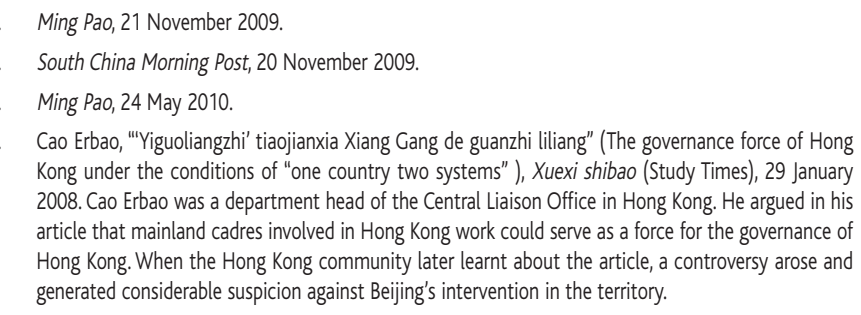

Cao Erbao, "'Yiguoliangzhi' tiaojianxia Xiang Gang de guanzhi liliang" (The governance force of Hong Kong under the conditions of "one country two systems" ), Xuexi shibao (Study Times), 29 January 2008. Cao Erbao was a department head of the Central Liaison Office in Hong Kong. He argued in his article that mainland cadres involved in Hong Kong work could serve as a force for the governance of Hong Kong. When the Hong Kong community later learnt about the article, a controversy arose and generated considerable suspicion against Beijing's intervention in the territory. 
tween Beijing and Hong Kong on the issue of political reform. If this was indeed the case, then it should have observed the principles of openness and high transparency instead of selectively meeting some pro-democracy groups based on united front considerations.

\section{Beijing's strong influence}

Hong Kong people understand that the issue of electoral reform will be determined in Beijing and not by the HKSAR government. Symbolically, the protest rally for democracy held on 1 January 2010 abandoned the usual route and chose the Central Liaison Office, the representative of the central government in Hong Kong, as its destination. It is expected that more pro-democracy protest rallies will target the Central Liaison Office in the future. ${ }^{(9)}$

The community also realises that the Chinese leadership is reluctant to grant genuine democracy to the territory. Although a significant majority of Hong Kong people is in support of democracy, it is unwilling to confront Beijing. In view of the hard-line position, most Hong Kong people tend to return to their traditional apathy. After all, the community is basically satisfied with the status quo of stability and prosperity and is reluctant to sacrifice it in the pursuit of democracy.

When President Hu Jintao visited Macau in December 2009, he openly stated that the central government gave "a high rating" to the work of the outgoing Edmund Ho Hau-wah administration and its contribution to Macau and the nation. (10) When Hong Kong's Chief Executive, Donald Tsang Yam-kuen, made his duty visit to Beijing at the end of the month, he was told by Premier Wen Jiabao to resolve "some deep-rooted conflicts" in Hong Kong society and was asked by President Hu to handle the territory's constitutional reforms "in an appropriate manner." (11) Premier Wen's remarks were broadly viewed as a public rebuke. Apparently the central leadership is happy with the situation in Macau and dissatisfied with the political and social contradictions in Hong Kong.

What, then, is the political situation in Macau? There was only one candidate, Fernando Chui Sai-on, in the 2009 Chief Executive election, and therefore no competition and no public debate. Once Beijing indicated that it had a preferred candidate, the issue was settled. Much more shocking was the earlier election of the Election Committee - there were only 300 candidates to fill the same number of seats, hence no competition, no campaigning, and no formal election.

The so-called Macau Street political culture is often described as follows: Macau is a small place, and nearly all community leaders of any standing are related to one another in some way. Electoral competition and controversy are to be avoided for the sake of future co-operation and maintaining harmony within the community. Organisations outside the establishment have secured only three seats in the legislature, and there is a limit to their political participation and mobilisation.

The domination of the establishment and the lack of a developed civil society can be attributed to two factors. First, the local mass media are almost totally controlled by the establishment. Macau's media do not criticise its government or the Chinese government. Macau people have ample access to Hong Kong newspapers, radio, and television - none of which carry much news about Macau. The only independent media to be found are in the Portuguese or English languages, serving the relatively small expatriate community. Second, almost every recognised civic group in Macau receives generous financial support from the government, which in turn has been enjoying ample revenue from the casino industry in recent years. Even the powerful Catholic Church has to maintain good relations with the government in order to maintain its impressive social services. The only outlets for social grievances are occasional protest rallies, such as on May Day, which are usually confined to livelihood issues.

Hong Kong is still quite different. All parties concerned appreciate that rule of law and freedom of information are essential to the territory's functioning as an international financial and business services centre. If these two assets are severely eroded, Hong Kong will become just another Chinese city with no edge over Shanghai and other coastal cities. But the lesson of Macau is clear: unless Hong Kong people work hard to protect their rights, civil society can degenerate. Some of the hallmarks of Macau politics are beginning to emerge in Hong Kong. Self-censorship in the media is becoming increasingly serious; rational, in-depth discussion of political issues is becoming much less frequent. The public is becoming more apathetic politically, expressing their grievances mainly through protest actions to make headlines.

In the long-term, Hong Kong people realise that the territory's economy is increasingly dependent on that of the mainland (see Table 1). This rising dependence has been accompanied by a relative decline in Hong Kong's international economic competitiveness. Over the past decade, the leaders of Shanghai have no longer looked to the territory as a model for emulation; they have turned their eyes to New York and London. At the time of Hong Kong's return to China in 1997, the Guangdong authorities were eager to establish closer economic ties with the HKSAR, but Hong Kong's top civil servants wanted to avoid a high degree of economic integration with the mainland and were cool to Guangdong's overtures. In recent years, Guangdong has been following in the footsteps of Shanghai, trying to attract investment from multinational corporations listed in the Fortune 500. The value of Hong Kong as an economic partner has thus been falling. In sum, dependence on the mainland and the decline in relative bargaining power has exacerbated Hong Kong people's willingness to accept Beijing's position on the territory's electoral reforms.

At the same time, Hong Kong people's confidence in China's future continues to strengthen (Table 2). Apparently this is related to their increasingly positive perception of mainland China's international standing. A public opinion survey conducted by the New Youth Forum in March 2009 revealed that 86 percent of the respondents thought that China had considerable international influence; about 77 percent believed that China would definitely or possibly overtake the US as a world superpower within 50 years; 80 percent felt that China was a peace-loving country; and 60 percent believed that China's development would not threaten the AsiaPacific region. ${ }^{(12)}$ The successful Beijing Olympics certainly helped; and most Hong Kong people believed that China, in contrast to the US, emerged from the recent global financial tsunami with its international status improved.

The recent economic difficulties and political controversies have nevertheless undermined the Hong Kong community's trust in the central gov-

9. Protest rallies organised by the pro-democracy movement usually start from Victoria Park in Causeway Bay and end at the government offices in Central. On 1 January 2010, the protest rally began in Central and ended at the Central Liaison Office in Sai Wan. See all major newspapers in Hong Kong on 2 January 2010.

10. South China Morning Post, 20 December 2009.

11. Ibid., 29 December 2009.

12. Ibid., 30 March 2009. 
Table 1 - Trade, Investment, and Tourism between Mainland China and Hong Kong, 1978-2009

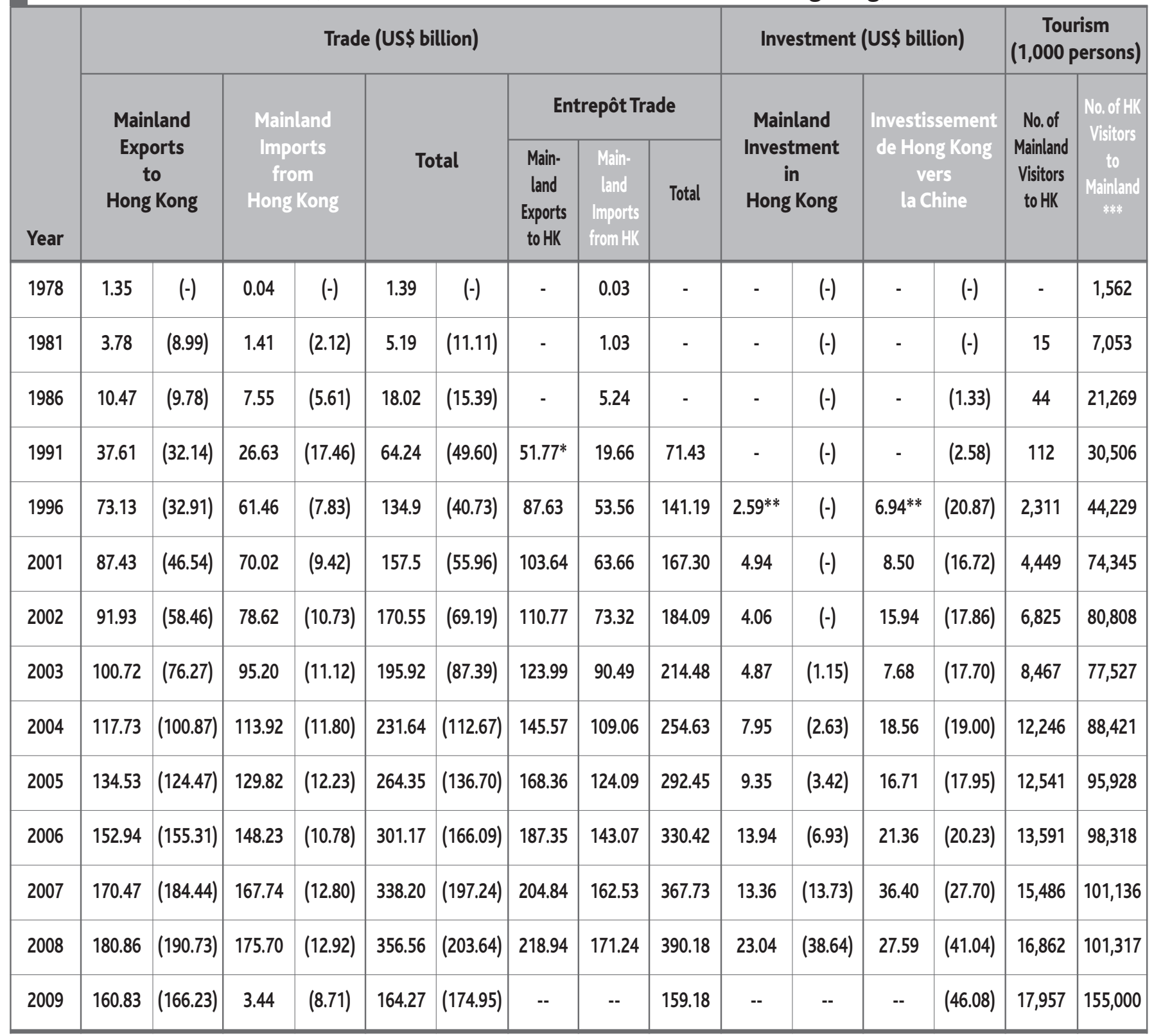

Notes: 1. Figures may not add up to the totals due to rounding. 2. "-" indicates that statistical data are unavailable, unknown, or negligible. 3 . Statistics from mainland Chinese sources are given in brackets. D 4. Figures for mainland imports from HK exclude HK's re-exports to China. 5. * Figure for 1992. $6 .{ }^{* *}$ Figures for 1998. $7 .{ }^{* * *}$ No. of Hong Kong visitors to the mainland includes visitors from Macau.

Source: Census and Statistics Department, The Government of the Hong Kong Special Administrative Region, "Hong Kong Statistics," http://www.censtatd.gov.hk/hong_kong_statistics/index.jsp; A Statistical Review of Tourism (1981, 1986, 1991, and 1996 issues), Hong Kong, Research Department, Hong Kong Tourism Association, 1982, 1987, 1992, and 1997; Hong Kong Tourism Board, Visitor Arrival Statistics (published monthly), http://partnernet.hktourismboard.com; State Statistical Bureau, People's Republic of China (comp.), China Statistical Yearbook (1983, 1987, 1992, 1997, 2003, 2004, 2006, 2008, and 2009 issues), China Statistics Press, Beijing, 1983, 1987, 1992, 1997, 2003, 2004, 2006, 2008, and 2009; and Ministry of Commerce, National Bureau of Statistics, and State Administration of Foreign Exchange, People's Republic of China, 2008 Niandu Zhongguo duiwai zhijie touzi tongji gongbao (2008 statistical bulletin of China's outward foreign direct investment), September 2009, http://hzs.mofcom.gov.cn/accessory/ 200909/1253868856016.pdf.

ernment and its confidence in "one country, two systems" (see Table 2). Given that the territory's economy is heavily dependent on the mainland economy and the central government's policy support, and that the HKSAR government was chosen by China's leaders, Hong Kong people might have held the central government responsible for the performance of their economy and government. But obviously the trends have been positive since 1997.

In recent years, Hong Kong people's trust in the central government has been considerably higher than its trust in the Hong Kong government, in contrast to the situation in the 1990s before the return of the territory to China. In a survey in December 2008 (one of the series recorded in Table 2),
56 percent of the respondents said they trusted the central government. By comparison, 42 percent of the respondents indicated that they trusted the HKSAR government, and 19 percent indicate that they distrusted it. The 14 percent gap between those who trusted the central government and those who trusted the HKSAR government was the greatest since the end of 2003. ${ }^{(13)}$

In early 1996, an opinion poll conducted by the Chinese University of Hong Kong revealed that 42 percent of the respondents trusted the British

13. Ibid., 7 January 2009. 
Table 2 - Hong Kong People's Confidence in China and Trust for the Chinese Leadership as Reflected by Public Opinion Surveys, 1997-2009 (half-yearly average)

\begin{tabular}{|c|c|c|c|c|c|c|}
\hline \multirow{2}{*}{ Date of Survey } & \multicolumn{2}{|c|}{$\begin{array}{l}\text { Confidence in China's Future } \\
\text { (A) }\end{array}$} & \multicolumn{2}{|c|}{$\begin{array}{l}\text { Trust in the Central Government } \\
\text { (B) }\end{array}$} & \multicolumn{2}{|c|}{$\begin{array}{c}\text { Confidence in } \\
\text { "One Country, Two Systems" (C }\end{array}$} \\
\hline & Confident & Not Confident & $\begin{array}{l}\text { Very Trust/ } \\
\text { Quite Trust }\end{array}$ & $\begin{array}{l}\text { Quite Distrust/ } \\
\text { Very Distrust }\end{array}$ & Confident & Not Confident \\
\hline July to December 2009 & $87.2 \%$ & $8.5 \%$ & $49.6 \%$ & $18.8 \%$ & $68.1 \%$ & $26.0 \%$ \\
\hline January to June 2009 & $88.2 \%$ & $8.2 \%$ & $52.6 \%$ & $15.4 \%$ & $72.5 \%$ & $21.7 \%$ \\
\hline July to December 2008 & $88.1 \%$ & $7.9 \%$ & $53.1 \%$ & $14.4 \%$ & $71.8 \%$ & $21.6 \%$ \\
\hline January to June 2008 & $87.9 \%$ & $7.9 \%$ & $54.9 \%$ & $13.4 \%$ & $74.6 \%$ & $18.7 \%$ \\
\hline July to December 2007 & $87.6 \%$ & $7.8 \%$ & $54.4 \%$ & $15.6 \%$ & $74.9 \%$ & $18.8 \%$ \\
\hline January to June 2007 & $87.5 \%$ & $8.1 \%$ & $49.9 \%$ & $15.5 \%$ & $72.9 \%$ & $20.8 \%$ \\
\hline July to December 2006 & $85.7 \%$ & $9.3 \%$ & $44.6 \%$ & $19.7 \%$ & $70.4 \%$ & $23.6 \%$ \\
\hline January to June 2006 & $85.0 \%$ & $9.3 \%$ & $48.5 \%$ & $18.7 \%$ & $69.4 \%$ & $22.6 \%$ \\
\hline July to December 2005 & $82.0 \%$ & $11.0 \%$ & $46.8 \%$ & $24.4 \%$ & $65.1 \%$ & $25.3 \%$ \\
\hline January to June 2005 & $79.0 \%$ & $11.4 \%$ & $43.2 \%$ & $24.7 \%$ & $57.2 \%$ & $28.2 \%$ \\
\hline July to December 2004 & $83.4 \%$ & $9.2 \%$ & $47.0 \%$ & $20.9 \%$ & $59.3 \%$ & $28.4 \%$ \\
\hline January to June 2004 & $82.6 \%$ & $8.8 \%$ & $40.0 \%$ & $25.6 \%$ & $51.7 \%$ & $33.1 \%$ \\
\hline July to December 2003 & $82.7 \%$ & $8.3 \%$ & $45.7 \%$ & $20.6 \%$ & $53.7 \%$ & $30.9 \%$ \\
\hline January to June 2003 & $79.1 \%$ & $11.0 \%$ & $37.6 \%$ & $29.4 \%$ & $49.2 \%$ & $38.4 \%$ \\
\hline July to December 2002 & $81.7 \%$ & $9.6 \%$ & $41.0 \%$ & $26.2 \%$ & $52.7 \%$ & $34.3 \%$ \\
\hline January to June 2002 & $81.1 \%$ & $8.6 \%$ & $48.6 \%$ & $20.6 \%$ & $58.7 \%$ & $28.3 \%$ \\
\hline July to December 2001 & $79.9 \%$ & $10.0 \%$ & $43.9 \%$ & $22.1 \%$ & $59.2 \%$ & $27.3 \%$ \\
\hline January to June 2001 & - & - & $33.8 \%$ & $31.1 \%$ & $56.7 \%$ & $30.4 \%$ \\
\hline July to December 2000 & - & - & $31.6 \%$ & $31.0 \%$ & $58.2 \%$ & $27.5 \%$ \\
\hline January to June 2000 & - & - & $31.9 \%$ & $27.3 \%$ & $62.0 \%$ & $22.5 \%$ \\
\hline July to December 1999 & - & - & $29.3 \%$ & $29.7 \%$ & $56.3 \%$ & $29.6 \%$ \\
\hline January to June 1999 & $78.6 \%$ & $10.5 \%$ & $27.3 \%$ & $27.4 \%$ & $57.7 \%$ & $28.3 \%$ \\
\hline July to December 1998 & - & - & $30.5 \%$ & $30.7 \%$ & $66.6 \%$ & $21.9 \%$ \\
\hline January to June 1998 & $71.0 \%$ & $15.0 \%$ & $28.7 \%$ & $30.1 \%$ & $64.5 \%$ & $20.8 \%$ \\
\hline July to December 1997 & $73.1 \%$ & $11.8 \%$ & $32.4 \%$ & $29.9 \%$ & $64.0 \%$ & $18.7 \%$ \\
\hline
\end{tabular}

Notes :

1. Question asked for (A) - Do you have confidence in China's future? The other option was "don't know/hard to say," which is not included in this table.

2. Question asked for (B) - On the whole, do you trust the Beijing Central Government? The other options were "half-half" and "don't know/hard to say," which are not included in this table.

3. Question asked for (C) - On the whole, do you have confidence in "One Country, Two Systems"? The other option was "don't know/hard to say," which is not included in this table.

Source: Public Opinion Programme, The University of Hong Kong, http://hkupop.hku.hk/, retrieved on 25 January 2010.

administration; those who trusted the Chinese amounted to less than 20 percent, while only 12 percent trusted the Chinese government. ${ }^{(14)} \mathrm{A}$ similar pattern emerged in various surveys on the same subject in the 1990s. Hence, the Chinese authorities should be satisfied with the achievements of its united front charm offensive in the territory. This trust in the central government and confidence in "one country, two systems" implies that Hong Kong people are less inclined to demand democracy as a checks and balances mechanism against Beijing, in contrast to the mentality of "the exploitation of democracy as a bulwark against communism," which hit its peak in the wake of the Tiananmen Incident in June 1989. ${ }^{(15)}$
In terms of Hong Kong people's identity, there have been positive changes in the long-term trends from Beijing's point of view, though the changes are more limited. As shown by Table 3, there has been a fairly steady decline in Hong Kong people identifying themselves as "Hong Kong citizens," and a shift toward identifying themselves as "Chinese Hong Kong citizens," though there was reversal of this trend in 2008 and 2009. Similarly, there has been a fairly steady rise in Hong Kong people identifying

14. Sing Tao Evening Post, 5 February 1996.

15. See Joseph Y. S. Cheng, "Prospects for Democracy in Hong Kong," in George Hicks (ed.), The Broken Mirror: China After Tiananmen, Harlow, Essex, UK, Longman Group UK Limited, 1990, pp. 278-295. 


\begin{tabular}{|c|c|c|c|c|c|c|}
\hline \multirow[b]{2}{*}{ Date of Survey } & \multicolumn{4}{|c|}{ (A) } & \multirow{2}{*}{$\begin{array}{c}\text { (B) } \\
\text { Strength of } \\
\text { Identity as a } \\
\text { HK Citizen }\end{array}$} & \multirow{2}{*}{$\begin{array}{c}\text { (C) } \\
\text { Strength of } \\
\text { Identity as a } \\
\text { Chinese Citizen }\end{array}$} \\
\hline & $\begin{array}{l}\text { Hong Kong } \\
\text { Citizen }\end{array}$ & $\begin{array}{l}\text { Chinese } \\
\text { Hong Kong } \\
\text { Citizen }\end{array}$ & $\begin{array}{l}\text { Hong Kong } \\
\text { Chinese } \\
\text { Citizen }\end{array}$ & $\begin{array}{l}\text { Chinese } \\
\text { Citizen }\end{array}$ & & \\
\hline July to December 2009 & $37.6 \%$ & $23.9 \%$ & $13.1 \%$ & $24.2 \%$ & 8.14 & 7.79 \\
\hline January to June 2009 & $24.7 \%$ & $32.0 \%$ & $13.3 \%$ & $29.3 \%$ & 7.83 & 7.72 \\
\hline July to December 2008 & $21.8 \%$ & $29.6 \%$ & $13.0 \%$ & $34.4 \%$ & 7.99 & 7.79 \\
\hline January to June 2008 & $18.1 \%$ & $29.2 \%$ & $13.3 \%$ & $38.6 \%$ & 7.80 & 8.02 \\
\hline July to December 2007 & $23.5 \%$ & $31.5 \%$ & $16.0 \%$ & $27.2 \%$ & 8.09 & 7.87 \\
\hline January to June 2007 & $23.4 \%$ & $31.8 \%$ & $16.7 \%$ & $26.4 \%$ & 8.00 & 7.66 \\
\hline July to December 2006 & $22.4 \%$ & $24.3 \%$ & $20.1 \%$ & $31.8 \%$ & 7.98 & 7.82 \\
\hline January to June 2006 & $24.8 \%$ & $25.1 \%$ & $14.9 \%$ & $34.6 \%$ & 7.79 & 7.68 \\
\hline July to December 2005 & $24.8 \%$ & $26.5 \%$ & $16.9 \%$ & $30.7 \%$ & 7.91 & 7.73 \\
\hline January to June 2005 & $24.0 \%$ & $21.2 \%$ & $14.7 \%$ & $36.4 \%$ & 7.77 & 7.56 \\
\hline July to December 2004 & $25.9 \%$ & $23.1 \%$ & $16.2 \%$ & $31.6 \%$ & 7.54 & 7.47 \\
\hline January to June 2004 & $28.0 \%$ & $21.2 \%$ & $14.3 \%$ & $33.0 \%$ & 7.54 & 7.48 \\
\hline July to December 2003 & $24.9 \%$ & $23.4 \%$ & $15.6 \%$ & $32.5 \%$ & 7.41 & 7.52 \\
\hline January to June 2003 & $32.6 \%$ & $20.8 \%$ & $13.5 \%$ & $30.7 \%$ & - & 7.54 \\
\hline July to December 2002 & $30.0 \%$ & $21.7 \%$ & $14.7 \%$ & $31.1 \%$ & - & 7.63 \\
\hline January to June 2002 & $29.9 \%$ & $20.7 \%$ & $15.5 \%$ & $30.4 \%$ & - & 7.76 \\
\hline July to December 2001 & $29.0 \%$ & $24.2 \%$ & $14.0 \%$ & $28.7 \%$ & - & 7.85 \\
\hline January to June 2001 & $33.8 \%$ & $20.0 \%$ & $14.7 \%$ & $28.3 \%$ & - & 7.78 \\
\hline July to December 2000 & $36.3 \%$ & $23.0 \%$ & $14.2 \%$ & $21.3 \%$ & - & 7.62 \\
\hline January to June 2000 & $37.5 \%$ & $22.5 \%$ & $15.9 \%$ & $19.0 \%$ & - & 7.50 \\
\hline July to December 1999 & $33.5 \%$ & $22.6 \%$ & $17.0 \%$ & $23.6 \%$ & - & 7.27 \\
\hline January to June 1999 & $41.4 \%$ & $22.0 \%$ & $13.2 \%$ & $17.5 \%$ & - & 7.02 \\
\hline July to December 1998 & $36.6 \%$ & $23.5 \%$ & $16.7 \%$ & $19.9 \%$ & - & 7.18 \\
\hline January to June 1998 & $32.2 \%$ & $18.3 \%$ & $17.4 \%$ & $28.2 \%$ & - & 7.10 \\
\hline July to December 1997 & $35.9 \%$ & $23.6 \%$ & $19.9 \%$ & $18.0 \%$ & - & 7.28 \\
\hline
\end{tabular}

Notes :

1. Question asked for (A) - You would identify yourself as a Hong Kong Citizen/Chinese Citizen/Hong Kong Chinese Citizen/Chinese Hong Kong Citizen. The other options were "other" and "don't know/hard to say," which are not included in this table.

2. Question asked for (B) - Please use a scale of $0-10$ to rate your strength of identity as a Hong Kong citizen, with 10 indicating extremely strong, 0 indicating extremely weak, and 5 indicating half-half. How would you rate yourself?

3. Question asked for (C) - Please use a scale of 0-10 to rate your strength of identity as a Chinese citizen, with 10 indicating extremely strong, 0 indicating extremely weak, and 5 indicating half-half. How would you rate yourself?

Source: Public Opinion Programme, The University of Hong Kong, http://hkupop.hku.hk/english/popexpress/ethnic/index.html, retrieved on 25 January 2010.

themselves as "Chinese citizens" rather than "Hong Kong Chinese citizens"; again there was a reversal of the trend from mid-2008 to mid-2009. A more perplexing phenomenon is that the strength of identity of Hong Kong people as Hong Kong citizens and as Chinese citizens have both been rising, though the latter again showed a small decline from mid-2008 to mid-2009. Stronger identification as "Chinese Hong Kong citizens" and "Chinese citizens" on the part of Hong Kong people may mean that they are more willing to accept reducing the differences between the territory and the mainland.
The influence of the pro-Beijing united front has certainly been expanding rapidly since 1997. The resources at its disposal have been most impressive. The Chinese authorities and the HKSAR government can reward united front activists with decorations, honours, prestigious positions such as deputies and delegates to the National Committee of the CPPCC as well as local counterparts, and appointments to various advisory committees of the HKSAR government. In many ways, the united front is becoming the most influential social club in the territory, where one can establish business ties and raise one's social profile. Deputies to the NPC and delegates 
Table 4 - Gross Domestic Product (GDP) of Hong Kong, 1997-2009

\begin{tabular}{|c|c|c|c|c|c|c|c|c|c|c|}
\hline \multirow[b]{3}{*}{ Year } & \multicolumn{4}{|c|}{ GDP } & \multirow{2}{*}{\multicolumn{2}{|c|}{$\begin{array}{l}\text { Implicit price } \\
\text { deflator of GDP }\end{array}$}} & \multicolumn{4}{|c|}{ Per capita GDP } \\
\hline & \multicolumn{2}{|c|}{$\begin{array}{c}\text { At current } \\
\text { market prices }\end{array}$} & \multicolumn{2}{|c|}{$\begin{array}{l}\text { At chained } \\
\text { (2007) dollars }\end{array}$} & & & \multicolumn{2}{|c|}{$\begin{array}{c}\text { At current } \\
\text { market prices }\end{array}$} & \multicolumn{2}{|c|}{$\begin{array}{l}\text { At chained } \\
\text { (2007) dollars }\end{array}$} \\
\hline & $\begin{array}{l}\text { HK\$ } \\
\text { million }\end{array}$ & $\begin{array}{c}\% \\
\text { change }\end{array}$ & $\begin{array}{l}\text { HK\$ } \\
\text { million }\end{array}$ & $\begin{array}{c}\% \\
\text { change }\end{array}$ & $\begin{array}{c}(2007= \\
100)\end{array}$ & $\begin{array}{c}\% \\
\text { change }\end{array}$ & HK\$ & $\begin{array}{c}\% \\
\text { change }\end{array}$ & HK\$ & $\begin{array}{c}\% \\
\text { change }\end{array}$ \\
\hline 1997 & $1,365,024$ & 11.0 & $1,113,824$ & 5.1 & 122.6 & 5.7 & 210,350 & 10.1 & 171,640 & 4.2 \\
\hline 1998 & $1,292,764$ & -5.3 & $1,046,700$ & -6.0 & 123.5 & 0.8 & 197,559 & -6.1 & 159,955 & -6.8 \\
\hline 1999 & $1,266,668$ & -2.0 & $1,073,453$ & 2.6 & 118.0 & -4.5 & 191,731 & -3.0 & 162,484 & 1.6 \\
\hline 2000 & $1,317,650$ & 4.0 & $1,158,807$ & 8.0 & 113.7 & -3.6 & 197,697 & 3.1 & 173,865 & 7.0 \\
\hline 2001 & $1,299,218$ & -1.4 & $1,164,568$ & 0.5 & 111.6 & -1.9 & 193,500 & -2.1 & 173,446 & -0.2 \\
\hline 2002 & $1,277,314$ & -1.7 & $1,186,008$ & 1.8 & 107.7 & -3.5 & 189,397 & -2.1 & 175,859 & 1.4 \\
\hline 2003 & $1,234,761$ & -3.3 & $1,221,659$ & 3.0 & 101.1 & -6.2 & 183,449 & -3.1 & 181,503 & 3.2 \\
\hline 2004 & $1,291,923$ & 4.6 & $1,325,091$ & 8.5 & 97.5 & -3.5 & 190,451 & 3.8 & 195,340 & 7.6 \\
\hline 2005 & $1,382,590$ & 7.0 & $1,418,935$ & 7.1 & 97.4 & -0.1 & 202,928 & 6.6 & 208,263 & 6.6 \\
\hline 2006 & $1,475,357$ & 6.7 & $1,518,541$ & 7.0 & 97.2 & -0.3 & 215,158 & 6.0 & 221,455 & 6.3 \\
\hline 2007\# & $1,615,455$ & 9.5 & $1,615,455$ & 6.4 & 100.0 & 2.9 & 233,248 & 8.4 & 233,248 & 5.3 \\
\hline 2008\# & $1,675,315$ & 3.7 & $1,650,556$ & 2.2 & 101.5 & 1.5 & 240,327 & 3.0 & 236,775 & 1.5 \\
\hline 2009 & $1,632,284$ & -2.6 & $1,604,999$ & -2.8 & 101.7 & 0.2 & 233,060 & -3.0 & 229,164 & -3.2 \\
\hline
\end{tabular}

Notes:

1. Figures in this table are the latest data released on 13 November 2009.

2. \# indicates that the figures will be finalised when data from all regular sources are incorporated.

Source: Census and Statistics Department, The Government of the Hong Kong Special Administrative Region, "Hong Kong Statistics - Statistical Tables." Retrieved from http://www.censtatd.gov.hk/hong_kong_statistics/statistical_tables/index. jsp?charsetID=1\&subjectID=12\&tableID=030 on 22 January 2010 and 22 August 2010.

to the National Committee of the CPPCC enjoy the privilege of meeting central government ministers and provincial heads at will; one can easily imagine how valuable this privilege can be for Hong Kong businessmen in China. Members of the advisory committee system of the HKSAR government likewise have good access to senior government officials. The large state-owned enterprises (SOEs) listed on the Stock Exchange of Hong Kong have been generous in supporting the united front's activities. Even grassroots leaders such as mutual aid committee chairmen of public housing estates have been treated to visits to the mainland, where they are pampered by local officials.

All of this easily explains why the pro-Beijing Democratic Alliance for the Betterment and Progress of Hong Kong (DAB) claims a membership of well over 10,000, while the largest pro-democracy party, the Democratic Party (DP), has a membership of about 600 , with only about one third remaining active. It is also significant that the DP and the Civic Party (CP), another pro-democracy party with strong appeal to liberal middle-class professionals, do not have any mid-level executives of major corporations as their formal member. While almost all major enterprises in Hong Kong have significant business activities in mainland China, their mid-level executives do not want to be associated with pro-democracy political parties that are critical of the Chinese authorities. As most of the media in Hong Kong are in the hands of the major business groups, self-censorship has been on the rise since the 1990s.

Since the mid-1980s, the pro-Beijing united front in Hong Kong has been gradually building an effective election machine in support of its candidates in various elections. Its mobilisation power and sophisticated cam- paign strategies were well demonstrated in the Legislative Council elections in 2004 and 2008 as well as in the District Council elections in 2003 and 2007. (16)

The Chinese leadership is trapped in a fundamental dilemma. It has been trying hard to support Hong Kong economically in line with the ultimate objectives of ensuring political stability and demonstrating to the world that Beijing can administer the territory better than London. This active support and intervention has made Hong Kong people aware of their dependence on the Mainland, but they are also concerned with maintaining checks-and-balances mechanisms through support for the pro-democracy movement. Since Chinese leaders understand that they lack complete control over Hong Kong's political scene, they have been reluctant to allow genuine local democracy. They therefore have failed to win the hearts of those who still vote for the pro-democracy candidates in elections, and must absorb part of the blame for the unsatisfactory performance of the local government. ${ }^{(17)}$ As indicated above, it seems that economic difficul-

16. For some observations on the operation of this effective election machinery on the part of the proBeijing united front, see the author's "Introduction - Hong Kong Since Its Return to China: A Lost Decade?", in his edited volume, The Hong Kong Special Administrative Region in Its First Decade, Hong Kong, City University of Hong Kong Press, 2007, pp. 43 and 46-47.

17. Despite some signs of economic recovery, dissatisfaction with the Donald Tsang administration was on the rise at the end of 2009. According to the series of public opinion surveys conducted by the Public Opinion Programme of the University of Hong Kong, a poll at the end of October 2009 showed that 25.4 percent of the respondents were very satisfied/ quite satisfied with Donald Tsang's policy direction, 28.8 percent said half-half, and 41 percent were quite dissatisfied/ very dissatisfied with his policy direction. In another survey during the same period, 34.6 percent of the respondents indicated that they would vote for Donald Tsang (if they had the right to vote and the election was to be held tomorrow), while 48.5 percent said that they would not. Information is available at http://hkupop.hku.hk/. 
Table 5 - Table Statistics on Labour Force, Unemployment, and Underemployment in Hong Kong, 1997-2009

\begin{tabular}{|c|c|c|c|c|c|c|}
\hline \multirow{2}{*}{ Year } & \multicolumn{2}{|c|}{ Labour Force } & \multirow{2}{*}{$\begin{array}{l}\text { Unemployed } \\
\text { (thousand) }\end{array}$} & \multirow{2}{*}{$\begin{array}{c}\text { Unemployment } \\
\text { rate (\%) }\end{array}$} & \multirow{2}{*}{$\begin{array}{l}\text { Underemployed } \\
\text { (thousand) }\end{array}$} & \multirow{2}{*}{$\begin{array}{c}\text { Underemployment } \\
\text { rate (\%) }\end{array}$} \\
\hline & $\begin{array}{l}\text { Number } \\
\text { (thousand) }\end{array}$ & $\begin{array}{c}\% \\
\text { change }\end{array}$ & & & & \\
\hline 1997 & $3,234.8$ & 2.3 & 71.2 & 2.2 & 37.1 & 1.1 \\
\hline 1998 & $3,276.1$ & 1.3 & 154.1 & 4.7 & 81.8 & 2.5 \\
\hline 1999 & $3,319.6$ & 1.3 & 207.5 & 6.2 & 96.9 & 2.9 \\
\hline 2000 & $3,374.2$ & 1.6 & 166.9 & 4.9 & 93.5 & 2.8 \\
\hline 2001 & $3,427.3$ & 1.6 & 174.3 & 5.1 & 84.8 & 2.5 \\
\hline 2002 & $3,472.6$ & 1.3 & 254.2 & 7.3 & 104.4 & 3.0 \\
\hline 2003 & $3,465.8$ & -0.2 & 275.2 & 7.9 & 121.9 & 3.5 \\
\hline 2004 & $3,512.8$ & 1.4 & 239.2 & 6.8 & 114.3 & 3.3 \\
\hline 2005 & $3,534.2$ & 0.6 & 197.6 & 5.6 & 96.3 & 2.7 \\
\hline 2006 & $3,571.8$ & 1.1 & 171.1 & 4.8 & 86.3 & 2.4 \\
\hline 2007 & $3,629.6$ & 1.6 & 145.7 & 4.0 & 79.2 & 2.2 \\
\hline 2008 & $3,648.9$ & 0.5 & 130.1 & 3.6 & 69.0 & 1.9 \\
\hline 2009 & $3,676.6$ & 0.8 & 196.7 & 5.4 & 86.4 & 2.3 \\
\hline
\end{tabular}

Notes: Figures in this table are the latest data updated on 19 August 2010.

Source: Census and Statistics Department, The Government of the Hong Kong Special Administrative Region, "Hong Kong Statistics - Statistical Tables." Retrieved from http://www.censtatd.gov.hk/hong_kong_statistics/statistical_tables/index.jsp?charsetID $=1 \&$ subject|D=12\&tableID=006 on 22 January 2010; and http://www.censtatd.gov.hk/hong_kong_statistics/statistical_tables/ index.jsp?charsetID=1\&tablelD=006 on 22 August 2010 .

ties and the bad performance of the HKSAR government have a spill-over effect on the community's trust in the central government and its confidence in "one country, two systems." More significant still, Chinese leaders' influence and intervention in Hong Kong have destroyed the appeal of the "one country, two systems" model for Taiwan.

\section{The HKSAR government's legitimacy deficit}

The British colonial administration won its legitimacy by performance. ${ }^{(18)}$ Even today, many Hong Kong people still compare it favourably with the C. H. Tung and Donald Tsang administrations. After 1997, the Chinese authorities responded to the political crises in the HKSAR by offering strong economic support. Their rationale was simple: if the economy improved, the people would largely be satisfied and they would be much less interested in democracy. Political stability would no longer be challenged.

When Donald Tsang visited Beijing on his duty trip in December 2006, he told the central government that "Hong Kong's economy is the best it has been in almost twenty years." (19) Many Hong Kong people disagreed, however, even in the period of economic boom. Based on the views expressed in various radio phone-in programmes, people did not feel they had benefited from economic growth in recent years.

A study by the Bauhinia Foundation, a think-tank close to Donald Tsang, revealed that the median household income in 2005 was still 15.8 percent lower than that in the previous peak year of 1997. More serious still, between 1996 and 2005, the number of households with a monthly income below HK\$8,000 rose by 76.5 percent, to more than 500,000 ; and their proportion of the total number of households rose from 13 percent to 22 percent. (20)
According to the Census and Statistics Department, in June 2009, there were 0.3944 million workers earning less than HK\$4,000 (about US\$500) per month, compared with 0.3 million in 2001. (21) This low-income category, sometimes described by sociologists as the "working poor," mainly consists of workers without skills and of low educational qualifications. As more than 90 percent of the territory's GDP comes from the service sector, the decline in the manufacturing industries means demand for unskilled workers has been falling fast. The hourly wage at MacDonald's outlets (around US\$2.5) is a good indicator of the surplus of unskilled labour.

A research project at the Chinese University of Hong Kong revealed that its comprehensive quality of life index dropped 3.5 percent in 2008 compared with that in 2007, almost back to the level in 2003, when the territory was badly hit by the SARS epidemic. Between 2007 and 2008, Hong Kong people's evaluation of the economy and of the affordability of their own accommodation likewise fell 30 percent and 33 percent, respectively. (22)

Dr. Ohmae Kenichi believes the vast majority of Japanese will fall into the lower-middle class socio-economic group because globalisation will widen the gap between rich and poor and exacerbate social polarisation. (23) Perhaps Hong Kong's new graduates can most easily associate with Dr.

18. See Joseph Y. S. Cheng, "Political Modernization in Hong Kong," The Journal of Commonwealth \& Comparative Politics, vol. XXVII, no. 3, November 1989, pp. 294-320.

19. South China Morning Post, 28 December 2006.

20. Ibid., 10 January 2007; and Ming Pao, 10 January 2007.

21. Ibid., 8 June 2009

22. Ibid., 14 August 2009

23. See Ohmae Kenichi, The Impact of Rising Lower-middle Class Population in Japan: What Can We Do About It (in Japanese), Tokyo, Kodansha, 2006 


\section{Table 6 - People's Satisfaction with the HKSAR Government - Half-yearly Average, 1997-2009}

Survey question: Are you satisfied with the overall performance of the HKSAR Government? (half-yearly average)

\begin{tabular}{|c|c|c|c|c|c|c|c|}
\hline Month of survey & $\begin{array}{c}\text { Total } \\
\text { sample }\end{array}$ & $\begin{array}{c}\text { Very } \\
\text { satisfied }\end{array}$ & $\begin{array}{c}\text { Quite } \\
\text { satisfied }\end{array}$ & Half-half & $\begin{array}{c}\text { Not quite } \\
\text { satisfied }\end{array}$ & $\begin{array}{c}\text { Very } \\
\text { dissatisfied }\end{array}$ & $\begin{array}{l}\text { Don't know/ } \\
\text { Hard to say }\end{array}$ \\
\hline July to December 2009 & 6,033 & $3.4 \%$ & $28.3 \%$ & $35.8 \%$ & $21.1 \%$ & $10.9 \%$ & $0.6 \%$ \\
\hline January to June 2009 & 6,068 & $3.1 \%$ & $24.9 \%$ & $40.4 \%$ & $20.5 \%$ & $10.7 \%$ & $0.4 \%$ \\
\hline July to December 2008 & 6,213 & $2.7 \%$ & $24.3 \%$ & $41.9 \%$ & $20.4 \%$ & $9.6 \%$ & $1.1 \%$ \\
\hline January to June 2008 & 6,120 & $5.4 \%$ & $42.2 \%$ & $37.3 \%$ & $10.2 \%$ & $3.9 \%$ & $1.0 \%$ \\
\hline July to December 2007 & 6,072 & $5.2 \%$ & $46.4 \%$ & $35.1 \%$ & $9.0 \%$ & $3.2 \%$ & $1.1 \%$ \\
\hline January to June 2007 & 7,084 & $5.4 \%$ & $42.0 \%$ & $39.1 \%$ & $9.3 \%$ & $2.9 \%$ & $1.2 \%$ \\
\hline July to December 2006 & 6,076 & $4.2 \%$ & $37.8 \%$ & $41.7 \%$ & $11.4 \%$ & $3.7 \%$ & $1.1 \%$ \\
\hline January to June 2006 & 7,113 & $5.8 \%$ & $45.7 \%$ & $36.5 \%$ & $8.5 \%$ & $2.4 \%$ & $1.1 \%$ \\
\hline July to December 2005 & 6,097 & $5.2 \%$ & $44.0 \%$ & $35.7 \%$ & $9.5 \%$ & $3.1 \%$ & $2.4 \%$ \\
\hline January to June 2005 & 6,109 & $2.9 \%$ & $26.2 \%$ & $37.9 \%$ & $20.2 \%$ & $8.6 \%$ & $4.3 \%$ \\
\hline July to December 2004 & 6,148 & $2.7 \%$ & $17.5 \%$ & $35.3 \%$ & $27.6 \%$ & $14.2 \%$ & $2.8 \%$ \\
\hline January to June 2004 & 6,207 & $1.9 \%$ & $13.0 \%$ & $33.1 \%$ & $30.6 \%$ & $18.1 \%$ & $3.5 \%$ \\
\hline July to December 2003 & 7,364 & $1.5 \%$ & $12.2 \%$ & $26.9 \%$ & $35.3 \%$ & $21.3 \%$ & $3.0 \%$ \\
\hline January to June 2003 & 6,293 & $1.1 \%$ & $14.3 \%$ & $25.6 \%$ & $36.9 \%$ & $18.6 \%$ & $3.6 \%$ \\
\hline July to December 2002 & 6,260 & $1.0 \%$ & $17.0 \%$ & $28.1 \%$ & $37.9 \%$ & $11.3 \%$ & $4.8 \%$ \\
\hline January to June 2002 & 6,217 & $1.3 \%$ & $23.7 \%$ & $31.3 \%$ & $32.8 \%$ & $6.1 \%$ & $4.9 \%$ \\
\hline July to December 2001 & 6,321 & $1.0 \%$ & $19.2 \%$ & $30.9 \%$ & $33.4 \%$ & $10.5 \%$ & $5.0 \%$ \\
\hline January to June 2001 & 6,348 & $1.3 \%$ & $25.3 \%$ & $35.0 \%$ & $26.7 \%$ & $6.5 \%$ & $5.2 \%$ \\
\hline July to December 2000 & 6,324 & $1.5 \%$ & $19.9 \%$ & $31.3 \%$ & $32.1 \%$ & $9.6 \%$ & $5.7 \%$ \\
\hline January to June 2000 & 4,240 & $1.6 \%$ & $22.4 \%$ & $39.1 \%$ & $22.9 \%$ & $9.0 \%$ & $5.1 \%$ \\
\hline July to December 1999 & 3,205 & $1.4 \%$ & $22.8 \%$ & $39.2 \%$ & $23.6 \%$ & $8.0 \%$ & $5.0 \%$ \\
\hline January to June 1999 & 4,213 & $0.7 \%$ & $24.5 \%$ & $39.9 \%$ & $26.3 \%$ & $5.4 \%$ & $3.2 \%$ \\
\hline July to December 1998 & 4,755 & $1.0 \%$ & $21.7 \%$ & $35.8 \%$ & $29.0 \%$ & $8.0 \%$ & $4.6 \%$ \\
\hline January to June 1998 & 3,744 & $0.8 \%$ & $27.4 \%$ & $38.7 \%$ & $23.0 \%$ & $4.6 \%$ & $5.5 \%$ \\
\hline July to December 1997 & 3,181 & $1.9 \%$ & $40.7 \%$ & $32.7 \%$ & $13.6 \%$ & $1.9 \%$ & $9.3 \%$ \\
\hline
\end{tabular}

Source: Public Opinion Programme, The University of Hong Kong, "People's Satisfaction with the HKSAR Government - half-yearly average." Retrieved from http://hkupop.hku.hk/english/popexpress/ sargperf/sarg/halfyr/datatables.html on 22 January 2010.

Ohmae's arguments. The median monthly salary of new graduates is between $\operatorname{HK} \$ 10,000$ and $\operatorname{HK} \$ 11,000$; many also owe the government HK\$200,000 or so in student loans. Unless they can depend on their parents for food and accommodation, they will have difficulty maintaining a middle-class lifestyle. Neither can they expect steady promotions or salary increases. Many still earn a monthly salary of HK\$20,000 to $\$ 25,000$ after more than a decade of employment and cannot achieve meaningful breakthroughs in their careers.

Before 1997, unemployment was not a concern in Hong Kong. The community believed that anyone who was willing to work should have no difficulty finding a job. In recent years, it has had to accept an unemployment rate higher than those in the United States and United Kingdom. Hence, even those who are gainfully employed worry about the employment of their next generation.
The unemployment issue has been compounded by the widening gap between rich and poor. It has been reported that Hong Kong people have the highest individual net worth in the world, amounting to US\$202,000. According to a global study by the United Nations' World Institute for Development Economics Research in 2006, Hong Kong was ahead of Luxembourg, Switzerland, and the United States, which ranked second, third, and fourth respectively, while Japan ranked ninth and Singapore twelfth. (24) From 1981 to 2001, Hong Kong's Gini coefficient steadily rose from 0.451 to 0.525 (see Table 7a); in terms of this measurement of income distribution, Hong Kong compared rather unfavourably with developed countries, and was in a situation comparable to Argentina and Zambia (see Table 7b). Up to a third of Hong Kong's labour force has nine years of formal edu-

24. South China Morning Post, 7 December 2006. 
Table 7 (a) - Gini Coefficient of Hong Kong

\begin{tabular}{|c|c|c|c|c|c|c|c|}
\hline & 1981 & 1986 & 1991 & 1996 & 2001 & 2006 & 2007 \\
\hline Gini Coefficient & 0.451 & 0.453 & 0.476 & 0.518 & 0.525 & 0.533 & 0,434 \\
\hline
\end{tabular}

Source: Census and Statistics Department of the Hong Kong Government, 1991 Population Census Main Report, Hong Kong, Government Printer, 1992; Census and Statistics Department, The Government of the Hong Kong Special Administrative Region, Population Census 2001 Main Report - Volume I, Hong Kong, Printing Department, 2002; and Census and Statistics Department, The Government of the Hong Kong Special Administrative Region, 2006 Population By-census - Thematic Report: Household Income Distribution in Hong Kong, retrieved from http://www.bycensus2006.gov.hk/FileManager/EN/Content_962/06bc_hhinc.pdf on 22 January 2010.

Tableau 7 (b) - Gini Coefficients of Hong Kong and Selected Economies

\begin{tabular}{l|c|c}
\hline \multicolumn{1}{c}{ Region/Country } & Gini Coefficient & Survey year \\
\hline South Africa & 0.578 & 2000 \\
\hline Brazil & 0.550 & 2007 \\
\hline Hong Kong, China & 0.533 & 2006 \\
\hline United Kingdom & 0.510 & $2004 / 05$ \\
\hline Canada & 0.510 & 2004 \\
\hline Zambia & 0.507 & 2004 \\
\hline Argentina & 0.500 & 2005 \\
\hline Singapore & 0.481 & 2000 \\
\hline United States & 0.450 & 2005 \\
\hline Taiwan & 0.340 & 2007 \\
\hline South Korea & 0.316 & 1998 \\
\hline Germany & 0.283 & 2000 \\
\hline Sweden & 0.250 & 2000 \\
\hline
\end{tabular}

Source: The figures for Hong Kong, Canada, the United Kingdom, Singapore, and the United States are from the Census and Statistics Department, The Government of the Hong Kong Special Administrative Region, 2006 Population By-census - Thematic Report: Household Income Distribution in Hong Kong, retrieved from http://www.bycensus2006.gov.hk/FileManager/EN/Content_962/06bc_hhinc.pdf on 22 January 2010; the figures for Taiwan is from Council for Economic Planning and Development, Executive Yuan, Republic of China, Taiwan Statistical Data Book 2009, Taipei, Council for Economic Planning and Development, Executive Yuan, June 2009; and the remaining figures are from the database of The World Bank Group, World Development Indicators (WDI) Online.

cation or less; they will naturally find it difficult to benefit from the territory's economic growth. Exacerbated income inequality easily leads to a sense of grievance and possibly also to social instability.

In the era of the British colonial administration, the free market led to the concentration of wealth and the unequal distribution of income. In the colonial political system, however, power was highly concentrated among the expatriate senior officials of the colonial government, who were perceived to be neutral, efficient, and largely free of corruption. This separation of political power and wealth in fact constituted a form of checks and balances. But since the return of Hong Kong to China, most people perceive a rapid expansion of influence over the HKSAR government on the part of the major business groups. The latter have experienced rapid asset growth and have significant investment projects on the mainland. They therefore enjoy good access to China's top leaders, who are eager to attract external investment as well as maintain investor confidence in Hong Kong. Business leaders' assessment of the HKSAR government's performance have apparently had considerable impact on Chinese leaders' evaluation of the Tung and Tsang administrations, which in turn have shown great respect for the interests of major local business groups.

In recent years, critics of the HKSAR government often illustrate the collusion between the government and local business interests with the following examples. Middle-class families spend their life savings on their accommodation, while real estate developers refuse to reveal the exact measurements of their flats. Working people make monthly contributions to their pension funds and various insurance schemes, but do not even know how much they are paying in commissions and management fees. Supermarkets provide false information on their discounts, and have not been sanctioned after media reports; worse still, consumers have no other options. These examples vividly reflect the oligopolistic control of the market by the territory's major business groups, while the government has been reluctant to introduce fair competition legislation to protect the interests of consumers and small investors.

The perception of government-business collusion has been exacerbated by the fact that many top government officials join major corporations soon after their retirement with very attractive remuneration packages. At the same time, the official advisory committee system has been dominated by a small elite of 300 or 400 people, including spouses and children of top business leaders. Worse still, some of them are so much favoured by the government that they sit on more than ten advisory committees, with their tenures extending beyond six years, in violation of established conventions. From the very first policy address of $\mathrm{C}$. $\mathrm{H}$. Tung to the most recent one of the Tsang administration, the HKSAR government has been trying hard to maintain the territory's international competitiveness and a respectable economic growth rate. Obviously they have not been successful. In his last policy address delivered on 14 October 2009, Donald Tsang identified six industries with a strategic edge, and indicated that the government would support them with land grants and various subsidies. (25) In contrast to

25. For the contents of the policy address and the initial responses, see all major newspapers of Hong Kong on 15 October 2009 . 
Japan and the other "three little dragons of Asia," however, the HKSAR government does not control the banking and financial systems, nor does it possess state-owned investment funds and corporations to actively promote the development of strategic sectors. The Donald Tsang administration has therefore been perceived as ineffective even by the business community and the pro-Beijing united front.

The legitimacy deficit of the HKSAR government largely explains why it has been trying to avoid controversial issues. In an ageing society with a sharply falling fertility rate, the financial burden of social services will increase. Taxation will rise in the absence of administrative reforms. At this stage, Hong Kong's Mandatory Provident Fund is inadequate to provide for the community's retirement, and Hong Kong people have yet to tackle the long-term financing of their hospital services. Both the Tung and the Tsang administrations have been reluctant to expand the taxation base and introduce a value-added tax and/or ask Hong Kong people to increase their contribution to the Mandatory Provident Fund and pay for their own medical insurance. These are unpopular though essential policy programmes that a government without an electoral mandate and which has not been performing well can easily postpone, with the burden ultimately falling on the people further down the road.

\section{The challenges for the pro-democracy movement}

The pro-democracy movement has been in a difficult state. There is considerable frustration with the lack of progress, as no one expects any breakthrough soon. Even the political parties in the pro-democracy camp do not believe that democratisation is an issue with much political appeal. They can make very little impact on the government's policy-making process because the Tung and Tsang administrations have enjoyed the backing of a safe majority in the legislature; they do not have to lobby for the approval of the pro-democracy groups, which are treated as the opposition. In fact, there has been little meaningful consultation between the pro-democracy groups and the government.

The sense of political impotence on the part of the pro-democracy groups has been exacerbated by Hong Kong people's growing trust in China (see Table 2). Attacking the Chinese authorities' infringement on the community's freedoms and human rights has become less attractive to voters than before. The most important concerns of Hong Kong people are obviously the economy and unemployment, and the pro-democracy groups are not perceived as having much to offer.

Before Hong Kong's return to China, there was substantial moral and public opinion pressure to maintain unity within the pro-democracy camp. Such pressure evaporated soon after July 1997. In the frustration of the political wilderness, differences in political orientations have been exacerbated and can no longer be contained. These differences are most evident in the responses to the recently released Political Reform Proposals. The Civic Party (CP) and the League of Social Democrats (LSD) proposed an implicit referendum on the Political Reform Proposals through the resignation of one pro-democracy legislator in each of the five geographical constituencies. By-elections would then have to be held, and the resigned prodemocracy legislators would seek re-election on a common single-issue political platform of rejecting the HKSAR government's Political Reform Proposals and demanding "dual universal suffrage" as soon as possible. The rationale for this proposal was that this was the only way to mobilise the entire electorate of the territory to indicate its stand on the issue of democracy and, hopefully, to demonstrate to the HKSAR government, the Chinese authorities, and the international community that the pro-democracy movement still enjoyed majority support among the Hong Kong population.

The Democratic Party (DP) and the other pro-democracy groups representation in the legislature refused to support the "pseudo-referendum" plan, however. They asserted that it was too risky precisely because the electorate was apathetic regarding the issue of democratisation, and any loss in the five geographical constituencies would tarnish the image of the pro-democracy movement. The DP and like-minded pro-democracy groups worried about the effective electoral machinery of the pro-Beijing united front, and openly stated the importance of retaining the veto in the legislature concerning the Political Reform Proposals. (26)

The voter turnout rate for the Legislative Council by-elections on 16 May 2010 was 17.1 percent, with about 580,000 voters coming out to vote. As expected, both sides had scripts prepared and offered well-anticipated interpretations. ${ }^{27)}$ The Tsang administration and the pro-Beijing united front emphasised the low turnout and hence the failure of the "de facto referendum." Naturally they could report to the Chinese authorities that they had successfully discredited the campaign.

The crucial turning-point was Beijing's decision not to allow the pro-establishment parties to take part in the exercise. Chinese leaders obviously considered the "de facto referendum" a very sensitive precedent, and decided that the danger outweighed the potential of snatching one or two seats from the pro-democracy camp in the by-elections. In the end, the pro-establishment political parties refused to participate in the by-elections.

The Tsang administration was under pressure to do more to discredit the by-elections. Tsang's own decision not to vote certainly destroyed the neutrality of the executive branch in organising the elections of the legislature. It also compromised the spirit of the rule of law. Even if the administration believed that the legislators or political parties had exploited a loophole in the existing legislation by treating the resignations and the by-elections as a "de facto referendum," the government should still have followed the law, organised the elections, carried out the usual publicity work to encourage people to vote, etc. It could then consider closing the loophole afterwards.

A voter turnout rate of 17.1 percent was not a satisfactory performance for a "de facto referendum," but as a protest campaign, mobilising more than half a million people to say no to the Tsang administration's package of political reform proposals was quite an achievement, especially considering all the efforts to discredit the campaign by Chinese officials and the pro-Beijing united front. Meanwhile, Beijing continued to approach the democratisation issue only within a united front framework. On the day fol-

26. According to Annex I to the Basic Law, amendment of the method for selecting the Chief Executive "must be made with the endorsement of a two-thirds majority of all the members of the Legislative Council and the consent of the Chief Executive, and they shall be reported to the Standing Committee of the NPC for approval." According to Annex II to the Basic Law, amendment of the method for forming the Legislative Council "must be made with the endorsement of a two-thirds majority of all the members of the (Legislative) Council and the consent of the Chief Executive, and they shall be reported to the Standing Committee of the NPC for the record." The provisions were initially intended to make changes to the electoral system difficult, with the final decision-making power in the hands of the Chinese authorities; but these provisions also offer veto power to the pro-democracy legislators regarding any electoral reform proposals initiated by the HKSAR government, as long as they control more than 20 (one third) of the seats in the legislature. At present, they hold 23 seats in the Legislative Council.

27. See all major Hong Kong newspapers on 17 and 18 May 2010. 
Table 8 - Hong Kong People's Support for the Political Parties, August 1997 to November 2009

\begin{tabular}{|c|c|c|c|c|c|c|c|c|c|c|c|c|}
\hline $\begin{array}{lr} & \begin{array}{r}\text { Name of } \\
\text { Political } \\
\text { Party }\end{array} \\
\text { Date } \\
\text { of Survey }\end{array}$ & FTU & HKCTU & $\begin{array}{l}\text { Civic } \\
\text { Party }\end{array}$ & ADPL & DAB & DP & LP & LSD & $\begin{array}{l}\text { HKAS } \\
\text { PDMC }\end{array}$ & Frontier & AFA & NWS \\
\hline $19-23 / 11 / 2009$ & $1.7(2)$ & $51.3(3)$ & $0.2(4)$ & 50.1 (5) & $48.9(6)$ & $48.4(7)$ & 44.9 (9) & $40.6(10)$ & $46.6(8)$ & - & - & $51.8(1)$ \\
\hline $18-25 / 8 / 2009$ & $52.2(1)$ & $51.1(2)$ & $49.5(5)$ & $49.9(3)$ & $49.0(6)$ & $49.7(4)$ & $44.6(8)$ & $40.3(9)$ & $47.0(7)$ & - & $38.2(10)$ & - \\
\hline $19-22 / 5 / 2009$ & $52.6(1)$ & $51.7(2)$ & $51.3(3)$ & 49.9 (4) & $48.7(6)$ & $48.8(5)$ & $44.9(9)$ & $39.6(10)$ & $48.0(7)$ & $47.6(8)$ & - & - \\
\hline $16-18 / 2 / 2009$ & $52.9(1)$ & $51.6(2)$ & 49.7 (4) & 49.7 (5) & $50.4(3)$ & $48.3(6)$ & $43.5(9)$ & $43.8(8)$ & - & $46.5(7)$ & $36.5(10)$ & - \\
\hline $26-30 / 11 / 2008$ & $53.4(1)$ & $52.3(2)$ & $51.1(3)$ & $50.7(4)$ & $48.5(6)$ & $49.5(5)$ & $41.0(9)$ & $45.4(8)$ & - & $46.6(7)$ & $36.5(10)$ & - \\
\hline $18-20 / 8 / 2008$ & $53.3(1)$ & $51.7(3)$ & $52.4(2)$ & $51.0(4)$ & $48.5(5)$ & $47.7(6)$ & $47.4(7)$ & - & $44.0(9)$ & $46.2(8)$ & $35.4(10)$ & - \\
\hline $20-22 / 5 / 2008$ & $55.7(1)$ & $52.1(4)$ & $53.1(3)$ & $51.1(5)$ & $53.6(2)$ & $48.7(7)$ & $49.8(6)$ & - & $46.4(8)$ & $45.9(9)$ & $35.7(10)$ & - \\
\hline $18-20 / 2 / 2008$ & $53.7(1)$ & $51.5(4)$ & $51.8(2)$ & $49.3(5)$ & $51.6(3)$ & $48.6(7)$ & $49.1(6)$ & - & $45.1(9)$ & $46.2(8)$ & $35.7(10)$ & - \\
\hline $21-26 / 11 / 2007$ & $52.3(2)$ & $50.0(4)$ & $51.9(3)$ & $48.9(6)$ & $52.6(1)$ & $47.0(7)$ & $46.4(8)$ & - & - & $45.3(9)$ & $33.0(10)$ & $49.7(5)$ \\
\hline $13-16 / 8 / 2007$ & $55.0(1)$ & $50.0(6)$ & $50.7(4)$ & $50.2(5)$ & $54.8(2)$ & $48.0(7)$ & $52.3(3)$ & - & $44.1(9)$ & $45.4(8)$ & $34.3(10)$ & - \\
\hline $16-25 / 5 / 2007$ & $53.5(1)$ & $50.4(5)$ & $51.7(2)$ & $51.3(3)$ & $49.6(7)$ & $49.8(6)$ & $51.2(4)$ & - & 46.9 (8) & $46.1(9)$ & $35.7(10)$ & - \\
\hline $12-14 / 2 / 2007$ & $51.3(3)$ & $51.4(2)$ & $51.5(1)$ & $49.3(5)$ & $48.3(6)$ & $50.0(4)$ & $48.0(7)$ & - & $44.5(9)$ & $45.5(8)$ & $34.7(10)$ & - \\
\hline $20-24 / 11 / 2006$ & $53.2(1)$ & $51.5(4)$ & $51.9(2)$ & $50(5)$ & $49.2(6)$ & $48.4(8)$ & $49.1(7)$ & - & - & $47.3(9)$ & $36.9(10)$ & $51.6(3)$ \\
\hline $11-15 / 8 / 2006$ & $3.2(1)$ & 49.1 (3) & $49.4(2)$ & $49.1(4)$ & 49.1 (5) & $45.2(7)$ & $48.9(6)$ & - & $40.6(9)$ & $43.2(8)$ & $33.1(10)$ & - \\
\hline $18-25 / 5 / 2006$ & $54.2(1)$ & $52.6(2)$ & $52.2(3)$ & $50.5(5)$ & $51.1(4)$ & $47.4(7)$ & $50.2(6)$ & - & $44.8(9)$ & $46.6(8)$ & $37.6(10)$ & - \\
\hline $9-14 / 2 / 2006$ & $52.5(2)$ & $51.7(3)$ & $53.8(1)$ & $49.6(4)$ & $49.5(5)$ & $46.9(7)$ & $48.9(6)$ & - & 43.9 (9) & $45.1(8)$ & $35.6(10)$ & - \\
\hline $18-23 / 11 / 2005$ & $.7(2)$ & $1.7(3)$ & $53.8(1)$ & $48.0(6)$ & $7.5(7)$ & $48.2(5)$ & $49.7(4)$ & - & 45.7 (9) & $46.5(8)$ & $37.5(10)$ & - \\
\hline $22-25 / 8 / 2005$ & $52.0(2)$ & $51.1(3)$ & $54.1(1)$ & 49.7 (5) & $47.7(6)$ & $47.4(7)$ & $50.1(4)$ & - & $46.2(8)$ & $45.5(9)$ & $35.8(10)$ & - \\
\hline $21-24 / 5 / 2005$ & $52.2(3)$ & $52.5(2)$ & $54.0(1)$ & $48.3(5)$ & $46.5(7)$ & $49.0(4)$ & $47.4(6)$ & - & $45.2(9)$ & $46.4(8)$ & $36.3(10)$ & - \\
\hline $17-20 / 2 / 2005$ & $51.4(2)$ & $49.8(3)$ & $53.2(1)$ & $47.2(5)$ & 46.1 (7) & $47.0(6)$ & $48.6(4)$ & - & 44.0 (9) & $46.0(8)$ & $36.8(10)$ & - \\
\hline $15-17 / 11 / 2004$ & $50.8(3)$ & $52.1(2)$ & $54.1(1)$ & $49.2(4)$ & $45.0(9)$ & $49.0(5)$ & $48.6(6)$ & - & $46.3(8)$ & $47.6(7)$ & $37.9(10)$ & - \\
\hline $21-28 / 8 / 2004$ & $9.6(4)$ & $1.1(3)$ & $51.8(1)$ & $48.6(5)$ & $41.6(9)$ & $51.2(2)$ & $48.3(6)$ & - & $44.8(8)$ & $45.5(7)$ & $35.9(10)$ & - \\
\hline $10-13 / 5 / 2004$ & $51.6(5)$ & $53.7(2)$ & $54.3(1)$ & $51.8(4)$ & $42.5(9)$ & $53.2(3)$ & $49.9(6)$ & - & $47.4(8)$ & $48.3(7)$ & $39.4(10)$ & - \\
\hline $20-23 / 2 / 2004$ & $51.3(2)$ & $52.3(1)$ & - & $49.0(6)$ & $42.6(9)$ & $50.8(3)$ & $49.7(5)$ & - & 44.9 (8) & $47.0(7)$ & $37.3(10)$ & $50.6(4)$ \\
\hline $15-18 / 11 / 2003$ & $50.7(1)$ & $50.1(2)$ & - & $47.7(6)$ & $42.1(8)$ & $49.0(4)$ & $49.3(3)$ & - & - & $45.2(7)$ & $35.7(9)$ & $48.4(5)$ \\
\hline $18-20 / 8 / 2003$ & $49.0(4)$ & $51.3(1)$ & - & $48.2(6)$ & $41.2(9)$ & $50.1(3)$ & $50.7(2)$ & - & $45.3(8)$ & $46.0(7)$ & $35.4(10)$ & $48.6(5)$ \\
\hline $15-20 / 5 / 2003$ & $54.1(2)$ & 54.4 (1) & - & $52.4(3)$ & $47.9(8)$ & $49.8(6)$ & $49.3(7)$ & - & $47.5(9)$ & $50.6(5)$ & $39.1(10)$ & $52.3(4)$ \\
\hline $14-18 / 2 / 2003$ & $54.2(2)$ & $55.5(1)$ & - & $52.1(4)$ & $49.9(7)$ & $51.9(5)$ & $49.3(8)$ & - & $46.5(9)$ & $50.2(6)$ & $37.1(10)$ & $53.9(3)$ \\
\hline $1-5 / 11 / 2002$ & - & $55.8(1)$ & - & $54.4(3)$ & $53.3(4)$ & $51.8(5)$ & $50.3(7)$ & - & $47.6(8)$ & $51.3(6)$ & $37.7(9)$ & $54.7(2)$ \\
\hline $14-19 / 8 / 2002$ & - & $56.9(1)$ & - & $54.8(2)$ & $52.4(5)$ & $52.5(4)$ & $51.8(6)$ & - & $49.6(8)$ & $51.3(7)$ & $39.5(9)$ & $53.8(3)$ \\
\hline $14-16 / 5 / 2002$ & $8.8(1)$ & $57.9(2)$ & - & $56.0(3)$ & $55.1(4)$ & $51.2(7)$ & $52.5(6)$ & - & $47.9(9)$ & $50.5(8)$ & $40.0(10)$ & $54.0(5)$ \\
\hline $18-21 / 2 / 2002$ & $57.6(1)$ & $56.1(2)$ & - & $55.8(3)$ & $54.0(4)$ & $50.6(7)$ & $52.2(6)$ & - & - & $50.4(8)$ & $38.9(9)$ & $53.1(5)$ \\
\hline $15-20 / 11 / 2001$ & $57.0(1)$ & $56.1(2)$ & - & $54.9(3)$ & $52.7(5)$ & $51.7(6)$ & $50.3(7)$ & - & 48.1 (9) & $49.3(8)$ & $38.6(10)$ & $53.0(4)$ \\
\hline $17-24 / 8 / 2001$ & $56.7(1)$ & $55.5(2)$ & - & $52.5(4)$ & $52.7(3)$ & $50.7(6)$ & $48.1(9)$ & - & $48.4(8)$ & $49.5(7)$ & $37.7(10)$ & $51.6(5)$ \\
\hline $25-29 / 5 / 2001$ & $57.5(1)$ & $54.6(2)$ & - & $51.9(4)$ & $52.4(3)$ & $50.6(6)$ & $50.2(7)$ & - & $46.2(9)$ & $50.0(8)$ & $36.6(10)$ & $50.7(5)$ \\
\hline $19-21 / 2 / 2001$ & $60.1(2)$ & $60.5(1)$ & - & $55.8(5)$ & $55.5(6)$ & $57.4(4)$ & $53.5(9)$ & - & $55.3(7)$ & $54.4(8)$ & $46.2(10)$ & $58.1(3)$ \\
\hline $23-27 / 11 / 2000$ & $56.4(1)$ & $55.6(2)$ & - & $52.6(3)$ & $51.1(4)$ & $50.5(6)$ & 48.3 (8) & - & - & $48.4(7)$ & $37.5(9)$ & $51.0(5)$ \\
\hline $25-30 / 8 / 2000$ & $56.1(1)$ & $52.6(2)$ & - & $50.7(5)$ & $49.1(7)$ & $52.5(3)$ & $47.7(8)$ & - & $49.3(6)$ & $50.9(4)$ & 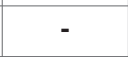 & - \\
\hline $2-5 / 6 / 2000$ & $58.7(1)$ & $54.8(2)$ & - & $51.1(6)$ & $51.9(5)$ & $52.7(3)$ & $49.1(8)$ & - & $50.2(7)$ & $52.3(4)$ & - & - \\
\hline $3 / 4 / 2000$ & $55.2(1)$ & $53.3(2)$ & - & $49.6(6)$ & $51.1(5)$ & $52.1(3)$ & $48.9(7)$ & - & $47.6(8)$ & $51.6(4)$ & - & - \\
\hline $1-2 / 2 / 2000$ & $56.6(1)$ & $54.5(2)$ & - & $50.0(4)$ & $50.3(3)$ & $48.5(6)$ & $47.7(7)$ & - & $46.7(8)$ & $48.6(5)$ & - & - \\
\hline 06/12/1999 & $56.3(1)$ & $51.1(2)$ & - & $50.0(4)$ & $50.2(3)$ & $49.8(5)$ & $47.3(8)$ & - & $47.6(7)$ & $47.8(6)$ & - & - \\
\hline 11-16/10/1999 & $53.1(1)$ & $51.1(2)$ & - & $45.7(8)$ & $48.6(5)$ & $50.4(3)$ & $47.3(6)$ & - & $48.9(4)$ & $46.9(7)$ & - & - \\
\hline 02/08/1999 & $53.2(1)$ & $51.4(3)$ & - & $48.9(5)$ & $47.0(7)$ & $52.0(2)$ & $47.3(6)$ & - & $49.1(4)$ & $49.1(4)$ & - & - \\
\hline
\end{tabular}




\begin{tabular}{|l|c|c|c|c|c|c|c|c|c|c|c|c|}
\hline $\begin{array}{r}\text { Name of } \\
\text { Political } \\
\text { Pate }\end{array}$ & FTU & HKCTU & $\begin{array}{l}\text { Civic } \\
\text { Party }\end{array}$ & ADPL & DAB & DP & LP & LSD & $\begin{array}{l}\text { HKAS } \\
\text { PDMC }\end{array}$ & Frontier & AFA & NWS \\
\hline $01 / 06 / 1999$ & $56.8(1)$ & $55.2(2)$ & - & $49.8(7)$ & $51.9(3)$ & $51.6(4)$ & $49.0(8)$ & - & $51.3(5)$ & $50.8(6)$ & - & - \\
\hline $09 / 04 / 1999$ & $55.8(1)$ & - & - & $49.9(5)$ & $51.3(4)$ & $55.5(2)$ & $48.9(7)$ & - & $49.7(6)$ & $51.4(3)$ & - & - \\
\hline $01 / 02 / 1999$ & $58.5(1)$ & - & - & $52.6(5)$ & $53.7(4)$ & $54.7(2)$ & $50.9(7)$ & - & $51.1(6)$ & $54.0(3)$ & - & - \\
\hline $1-2 / 12 / 1998$ & $57.5(1)$ & - & - & $50.8(6)$ & $52.4(4)$ & $55.9(2)$ & $51.1(5)$ & - & $50.5(7)$ & $52.5(3)$ & - & - \\
\hline $09 / 10 / 1998$ & $56.4(1)$ & - & - & $50.8(5)$ & $49.9(6)$ & $55.6(2)$ & $48.2(7)$ & - & $50.9(4)$ & $53.7(3)$ & - & - \\
\hline $04 / 08 / 1998$ & $57.7(1)$ & - & - & $51.6(6)$ & $52.6(4)$ & $57.5(2)$ & $51.3(7)$ & - & $52.2(5)$ & $54.9(3)$ & - & - \\
\hline $3-4 / 6 / 1998$ & $57.9(2)$ & - & - & - & $52.7(4)$ & $60.1(1)$ & $49.5(5)$ & - & - & $57.7(3)$ & - & - \\
\hline $07 / 04 / 1998$ & $58.7(2)$ & - & - & $54.6(3)$ & $54.4(4)$ & $59.0(1)$ & $53.0(5)$ & - & - & - & - & - \\
\hline $2-3 / 2 / 1998$ & $58.5(1)$ & - & - & $53.1(4)$ & $54.0(3)$ & $57.9(2)$ & $51.9(5)$ & - & - & - & - & - \\
\hline $2-3 / 12 / 1997$ & $60.1(1)$ & - & - & - & $53.7(4)$ & $58.5(2)$ & $50.1(5)$ & - & $53.8(3)$ & - & - & - \\
\hline $3-4 / 10 / 1997$ & $56.3(1)$ & - & - & - & $49.7(4)$ & $55.5(2)$ & $48.0(5)$ & - & $50.7(3)$ & - & - & - \\
\hline $06 / 08 / 1997$ & $61.4(2)$ & - & - & - & $57.2(4)$ & $63.8(1)$ & $56.0(5)$ & - & $59.9(3)$ & - & - & - \\
\hline
\end{tabular}

Notes:

1. FTU $=$ The Hong Kong Federation of Trade Unions;

HKCTU = Hong Kong Confederation Trade Unions;

ADPL = Hong Kong Association for Democracy and People's Livelihood;

$D A B=$ Democratic Alliance for the Betterment and Progress of Hong Kong;

DP = The Democratic Party;

$\mathrm{LP}=$ Liberal Party;

LSD = League of Social Democrats;

HKASPDMC $=$ Hong Kong Alliance in Support of Patriotic Democratic Movements of China;

AFA = April Fifth Action;

NWS = Neighbourhood \& Worker's Service Centre

2. The Civic Party was established in March 2006; the data for the Article 45 Concern Group were used from May 2004 to February 2006. The League of Social Democrats was formed in October 2006. The Frontier (a pro-democracy political group) merged with the Democratic Party in December 2008.

3. The question in each survey was: Please use a scale of 0-100 to rate your extent of support to XXX, with 0 indicating absolutely not supportive, 100 indicating absolutely supportive and 50 indicating half-half. How would you rate XXX?

4. The numbers in brackets indicate ranking in each of the surveys.

Source: Public Opinion Programme, the University of Hong Kong, "POP Polls: Rating of Top Ten Political Groups," from http:// http://hkupop.hku.hk.

lowing the by-elections, it was reported that central government officials would meet the Alliance for Universal Suffrage, an umbrella group led by the Democratic Party. It was subsequently revealed that the latter had indicated to the pro-Beijing united front earlier in December 2009 that it would be interested in a dialogue with the central government on the political reform issue. The dialogue surfaced after the Legislative Council byelections, and ultimately led to an agreement between the central government and the Democratic Party.

The central government accepted the Democratic Party's proposal that the five newly-created functional constituency seats for the District Councils would be voted for by the entire electorate except for those already enfranchised in the functional constituency elections. In this way, every voter in Hong Kong would have two votes in the Legislative Council elections in 2012. According to the Political Reform Proposals of the HKSAR government released in November 2009, there would be five more directly-elected Legislative Council seats, one for each of the five existing geographical constituencies; and five more functional constituency seats to be elected among the District Council members, following the NPCSC stipulation that the two types of constituencies would remain equal in terms of numbers of seats. In return for the concession, the Democratic Party Legislators voted in support of the government's Political Reform Proposals, which were then endorsed by the legislature. Due to the change in position of the Democratic Party, the pro-democracy camp lost its veto power in the legislature this time. However, this veto power is expected to remain effective regarding the democratisation issue in general.

The voting outcome in the Legislative Council on 24 and 25 June 2010 split the pro-democracy movement. (28) The Democratic Party and its supporters argued that the establishment of a dialogue with the central government following the Tiananmen Incident in 1989 was an important breakthrough, that the concession made by the central government was significant, and that they would continue to struggle for the ultimate realisation of democracy in the territory. Those who voted against the government's Political Reform Proposals, including the Civic Party, the LSD, the Hong Kong Confederation of Trade Unions, etc., insisted on a roadmap and a timetable, and considered the so-called "concession" by the central government to have increased both the number and the legitimacy of functional constituencies. There was also suspicion that the Democratic Party had refused to support the "pseudo-referendum" earlier because it had wanted to establish trust with the Chinese authorities to facilitate negotiations on political reform.

The chasm between the radical and conservative wings of the prodemocracy movement is now very clear. Since the Chinese authorities have no intention of allowing genuine democracy in the territory in the near future, there is no chance for the pro-democracy groups to form a government. Further, as indicated above, they have almost no influence on

28. See all major newspapers of Hong Kong on 24 and 25 June 2010. 
Table 9 - Popularity Ranking of the Pro-democracy Legislators, February 1997 to October 2009

\begin{tabular}{|c|c|c|c|c|}
\hline Date of Survey & $\begin{array}{l}\text { Pro-Democracy Legislator } \\
\text { As the Most Popular } \\
\text { Legislator Among } \\
\text { All } 60 \text { Legislators }\end{array}$ & $\begin{array}{l}\text { No. of Pro-Democracy } \\
\text { Legislator Among the Top } \\
\text { Three most Popular } \\
\text { Legislators in the entire } \\
\text { Legislature }\end{array}$ & $\begin{array}{l}\text { No. of Pro-Democracy } \\
\text { Legislator Among the } \\
\text { Top Five most Popular } \\
\text { Legislators in the entire } \\
\text { Legislature }\end{array}$ & $\begin{array}{l}\text { No. of Pro-Democracy } \\
\text { Legislators Among the } \\
\text { Top Ten most Popular } \\
\text { Legislators in the entire } \\
\text { Legislature }\end{array}$ \\
\hline $18-21 / 1 / 2010$ & Yes & 3 & 5 & 8 \\
\hline $15-19 / 10 / 2009$ & Yes & 2 & 3 & 8 \\
\hline $14-18 / 7 / 2009$ & Yes & 2 & 4 & 7 \\
\hline $21-23 / 4 / 2009$ & Yes & 2 & 4 & 8 \\
\hline $19-21 / 1 / 2009$ & Yes & 3 & 4 & 8 \\
\hline $22-24 / 10 / 2008$ & Yes & 3 & 4 & 7 \\
\hline $9-10 / 7 / 2008$ & No & 2 & 3 & 6 \\
\hline $16-18 / 4 / 2008$ & No & 2 & 2 & 6 \\
\hline $16-18 / 1 / 2008$ & No & 1 & 2 & 6 \\
\hline $22-25 / 10 / 2007$ & No & 2 & 2 & 6 \\
\hline $23-26 / 7 / 2007$ & No & 1 & 2 & 6 \\
\hline $17-20 / 4 / 2007$ & No & 2 & 2 & 7 \\
\hline $22-26 / 1 / 2007$ & No & 1 & 2 & 6 \\
\hline $23-27 / 10 / 2006$ & No & 1 & 2 & 6 \\
\hline $14-21 / 7 / 2006$ & No & 1 & 2 & 6 \\
\hline $18-21 / 4 / 2006$ & No & 1 & 2 & 6 \\
\hline $16-20 / 1 / 2006$ & No & 1 & 1 & 6 \\
\hline $9-13 / 11 / 2005$ & No & 1 & 2 & 6 \\
\hline $5-9 / 8 / 2005$ & No & 0 & 2 & 6 \\
\hline $9-12 / 5 / 2005$ & No & 1 & 2 & 6 \\
\hline $14-16 / 2 / 2005$ & No & 1 & 2 & 6 \\
\hline $8-11 / 11 / 2004$ & Yes & 1 & 1 & 5 \\
\hline $9-16 / 8 / 2004$ & Yes & 1 & 2 & 6 \\
\hline $3-7 / 5 / 2004$ & Yes & 1 & 2 & 6 \\
\hline $9-14 / 2 / 2004$ & Yes & 1 & 2 & 5 \\
\hline $10-12 / 11 / 2003$ & Yes & 1 & 2 & 6 \\
\hline $11-12 / 8 / 2003$ & Yes & 1 & 2 & 5 \\
\hline $2-7 / 5 / 2003$ & No & 1 & 2 & 5 \\
\hline $4-7 / 2 / 2003$ & No & 0 & 2 & 4 \\
\hline $1-5 / 11 / 2002$ & Yes & 2 & 3 & 5 \\
\hline $2-7 / 8 / 2002$ & Yes & 1 & 3 & 5 \\
\hline $2-7 / 5 / 2002$ & No & 1 & 2 & 5 \\
\hline $4-6 / 2 / 2002$ & Yes & 2 & 2 & 5 \\
\hline $1-5 / 11 / 2001$ & Yes & 2 & 2 & 5 \\
\hline $1-3 / 8 / 2001$ & Yes & 2 & 3 & 6 \\
\hline $19-23 / 5 / 2001$ & No & 2 & 2 & 5 \\
\hline $5-13 / 2 / 2001$ & No & 2 & 3 & 5 \\
\hline $14-16 / 11 / 2000$ & No & 2 & 2 & 5 \\
\hline $8-12 / 8 / 2000$ & Yes & 3 & 4 & 6 \\
\hline $26-30 / 5 / 2000$ & Yes & 3 & 4 & 6 \\
\hline $13 / 03 / 2000$ & Yes & 3 & 4 & 6 \\
\hline $21-24 / 1 / 2000$ & No & 1 & 2 & 4 \\
\hline 24/11/1999 & Yes & 2 & 2 & 5 \\
\hline
\end{tabular}




\begin{tabular}{|l|c|c|c|c|}
\hline Date of Survey & $\begin{array}{c}\text { Pro-Democracy Legislator } \\
\text { As the Most Popular } \\
\text { Legislator Among } \\
\text { All 60 Legislators }\end{array}$ & $\begin{array}{c}\text { No. of Pro-Democracy } \\
\text { Legislator Among the Top } \\
\text { Three most Popular } \\
\text { Legislators in the entire } \\
\text { Legislature }\end{array}$ & $\begin{array}{c}\text { No. of Pro-Democracy } \\
\text { Legislator Among the } \\
\text { Top Five most Popular } \\
\text { Legislators in the entire } \\
\text { Legislature }\end{array}$ & $\begin{array}{c}\text { No. of Pro-Democracy } \\
\text { Legislators Among the } \\
\text { Top Ten most Popular } \\
\text { Legislators in the entire } \\
\text { Legislature }\end{array}$ \\
\hline $27 / 09 / 1999$ & Yes & 2 & 4 & 7 \\
\hline $26 / 07 / 1999$ & Yes & 2 & 3 & 6 \\
\hline $24 / 05 / 1999$ & Yes & 3 & 3 & 6 \\
\hline $25 / 03 / 1999$ & Yes & 3 & 5 & 6 \\
\hline $26 / 01 / 1999$ & Yes & 3 & 5 & 6 \\
\hline $25 / 11 / 1998$ & Yes & 3 & 5 & 6 \\
\hline $23-24 / 9 / 1998$ & Yes & 3 & 5 & 6 \\
\hline $28 / 07 / 1998$ & Yes & 1 & 1 & 1 \\
\hline $24 / 03 / 1998$ & Yes & 1 & 1 & 1 \\
\hline $23 / 01 / 1998$ & No & 1 & 5 & 0 \\
\hline $24-25 / 11 / 1997$ & No & 0 & 1 & 1 \\
\hline $15-18 / 9 / 1997$ & No & 1 & 5 & 7 \\
\hline $22 / 07 / 1997$ & No & 3 & 5 & 1 \\
\hline $5-6 / 6 / 1997$ & Yes & 1 & 5 & 7 \\
\hline $19-20 / 5 / 1997$ & No & 3 & 5 & 1 \\
\hline $10-15 / 4 / 1997$ & Yes & 1 & 5 & 6 \\
\hline $17-18 / 3 / 1997$ & No & 3 & 5 & 1 \\
\hline $3-4 / 2 / 1997$ & Yes & & 5 & 7 \\
\hline
\end{tabular}

Source: Public Opinion Programme, the University of Hong Kong, "POP Polls: Rating of Top Ten Legislative Councillors," from http://hkupop.hku.hk.

the government's policy-making process. Under the circumstances, unity and discipline have decreasing appeal to politicians in the pro-democracy camp. Moreover, the multi-member, single-vote geographical constituencies in the Legislative Council elections exacerbate splittism. In the largest constituency, i.e., New Territories West, which returns eight legislators, a candidate can secure a seat with 8 to 9 percent of the votes cast. Hence, with the usual voter turnout rate at around 50 percent, a candidate can theoretically win a seat with the support of 4 or 5 percent of the constituency, as long as supporters can be motivated to come out and vote. Moving towards a more radical position may contribute to a sharp image appealing to a sufficient minority of the electorate. The LSD apparently has been very successful in following this type of strategy; it certainly has been attracting a lot of media attention. At the other end of the pro-democracy political spectrum, the Hong Kong Association for Democracy and People's Livelihood avoids controversial political issues and concentrates on district work in Sham Shui Po. Their different orientations make solidarity within the pro-democracy camp more problematic.

There are other types of problems as well. The frustrations of many "young Turks" in the radical wing of the pro-democracy movement are related to bottlenecks in their political careers. The two municipal councils were abolished in 2000, and there are very limited chances of getting elected to the Legislative Council as the "old guards" hold on to their seats. Junior politicians therefore spend many years on the District Councils, where remuneration is insufficient to support full-time political careers.

These inter-party and intra-party differences within the pro-democracy movement became public over the "pseudo-referendum" issue. Mutual re- criminations damaged the image of the entire pro-democracy movement while also discouraging its supporters. Worse still, the two founding elders of the DP, Martin Lee and Szeto Wah, had opposing views on the "pseudoreferendum." Szeto openly criticised Lee for his political immaturity, and accused youthful supporters of the "pseudo-referendum" of actually helping the Chinese Communist Party (CCP). (29)

When the pro-democracy movement organised a rally protesting against the Political Reform Proposals on New Year's Day 2010, the turnout was not expected to be impressive, with a general estimate that around 10,000 people would take part. The turnout actually reached 30,000 , due in part to the heavy sentence imposed on Liu Xiaobo. ${ }^{(30)}$ Another surprise was the enthusiastic opposition to the HKSAR government's costly plan for a highspeed railway from Kowloon linking to the high-speed railway system on the mainland. The opposition came from young people referred to as the "post-80s generation," who exhibit strong dissatisfaction with the establishment but have little respect and trust for the pro-democracy political parties. (31) There was also an unexpectedly high turnout of about 150,000 (32) for the June 4 anniversary candlelight vigil in 2010, with many young people in attendance. The commemoration events in 2011 was similar; the organizers claimed that more than 150,000 people participated.

29. See, for example, Ming Pao, 25 November 2009 and 14 December 2009; Oriental Daily News, 25 November 2009 and 29 November 2009; and Hong Kong Economic Journal, 14 December 2009.

30. See all major Hong Kong newspapers on 2 January 2010.

31. See all major Hong Kong newspapers on 9 January 92010.

32. According to the figures announced by Szeto Wah, Chairman of the Hong Kong Alliance, which organised the event. Different figures were claimed by different parties nonetheless. 
The frustrations and dissatisfaction of the "post-80s generation" have attracted a lot of attention, (33) highlighting the exacerbating problems of widening income disparity, declining opportunities for upward social mobility among young people, and a perception of worsening social injustice as government policies are seen to favour major business groups. These problems certainly erode the legitimacy of the HKSAR government, especially when the related grievances are sharply articulated by activists of the "post-80s generation."

The expectations of the younger generation reflect the community's changing values and demands, and members of the "post-80s generation" probably consider both the government and the pro-democracy parties to have failed them. While the Tung and Tsang administrations have been lacklustre at best in their socio-economic policy programmes, the prodemocracy movement also feels the pressure of the perception that its concentration on political reform issues is inadequate and cannot attract the sustained support of the majority of the population.

\section{Conclusion}

Most Hong Kong people understand that Chinese leaders have no intention of allowing genuine democracy in the territory, but they are unwilling to confront the Chinese authorities and are reluctant to sacrifice for the cause of democracy because the status quo is tolerable. Political apathy and the sense of political impotence in the community have therefore been growing in recent years. The pro-democracy movement finds it increasingly difficult to mobilise the people, and frustration over the lack of progress has exacerbated and publicised internal division. A major breakthrough in the foreseeable future seems unlikely, while maintaining the momentum of the movement has become a daunting challenge. These pressures, along with the resourcefulness and effectiveness of the pro-
Beijing united front electoral machinery, were keenly felt when many leaders of the pro-democracy movement appealed for caution and avoidance of risk in deciding against support for the "pseudo-referendum" proposal.

The difficulties of the pro-democracy movement have nevertheless not translated into advantages for the Tsang administration. Even the pro-Beijing united front is unhappy with the HKSAR government's performance, and blames its incompetence for the absence of an economic development strategy that would revive the territory's international competitiveness and relieve social polarisation. The Chinese leadership's hard-line position on political reform has exacerbated the legitimacy deficit of the Tsang administration, which is perceived by people on both sides of the HKSAR border as dependent on support from the Chinese authorities. Tsang's position has probably been salvaged by the fact that the Chinese leadership can hardly afford another forced resignation of a Chief Executive handpicked by Beijing.

Although Hong Kong people's confidence in China and their trust in the Chinese leadership as well as their identification with the mainland have been growing since the territory's return to China, the Chinese government's strong backing of the HKSAR has become a double-edged sword. Hong Kong people realise that decisions on local political reform are made in Beijing, and they also partly blame the Chinese authorities for the unsatisfactory performance of the HKSAR government, which is chosen by and accountable to Beijing.

The lose-lose situation can only be reversed by the Chinese leadership becoming enlightened and secure enough to allow genuine democracy in the territory. This is unlikely, however, as today's Chinese leaders still cannot accept erosion of the CCP's monopoly on political power, and the formula for political stability in China remains economic growth and an absence of democracy.
33. See Michael E. DeGolyez, Protest and Post-80s Youth, A Special Report on the Post-1980 Generation in Hong Kong, Hong Kong, Transition Project, Hong Kong Baptist University, 2010. The Central Policy Unit of the HKSAR government and the Applied Socio-Economic Research Centre of the Hong Kong University of Science and Technology jointly organised a seminar on "Youth and Social Change" on 17 December 2010 to examine the issues of the territory's "post-80s generation"; the papers are available at http://www.cpu.gov.hk/txttc/conference 20101217.htm. 